\title{
Summer ammonia measurements in a densely populated Mediterranean city
}

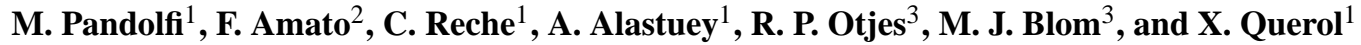 \\ ${ }^{1}$ Institute of Environmental Assessment and Water Research (IDAEA-CSIC), Barcelona, Spain \\ ${ }^{2}$ TNO, Built Environment and Geosciences, Dept. of Air Quality and Climate, Utrecht, The Netherlands \\ ${ }^{3}$ Energy Research Centre of the Netherlands, Department of Environmental Assessment, Petten, The Netherlands \\ Correspondence to: M. Pandolfi (marco.pandolfi@idaea.csic.es)
}

Received: 26 January 2012 - Published in Atmos. Chem. Phys. Discuss.: 20 April 2012

Revised: 13 July 2012 - Accepted: 6 August 2012 - Published: 20 August 2012

\begin{abstract}
Real-time measurements of ambient concentrations of gas-phase ammonia $\left(\mathrm{NH}_{3}\right)$ were performed in Barcelona (NE Spain) in summer between May and September 2011. Two measurement sites were selected: one in an urban background traffic-influenced area (UB) and the other in the historical city centre (CC). Levels of $\mathrm{NH}_{3}$ were higher at $\mathrm{CC}\left(5.6 \pm 2.1 \mu \mathrm{g} \mathrm{m}^{-3}\right.$ or $\left.7.5 \pm 2.8 \mathrm{ppbv}\right)$ compared with UB $\left(2.2 \pm 1.0 \mu \mathrm{g} \mathrm{m}^{-3}\right.$ or $\left.2.9 \pm 1.3 \mathrm{ppbv}\right)$. This difference is attributed to the contribution from non-traffic sources such as waste containers, sewage systems, humans and open markets more dense in the densely populated historical city centre. Under high temperatures in summer these sources had the potential to increase the ambient levels of $\mathrm{NH}_{3}$ well above the urban-background-traffic-influenced UB measurement station. Measurements were used to assess major local emissions, sinks and diurnal evolution of $\mathrm{NH}_{3}$. The measured levels of $\mathrm{NH}_{3}$, especially high in the old city, may contribute to the high mean annual concentrations of secondary sulfate and nitrate measured in Barcelona compared with other cities in Spain affected by high traffic intensity. Ancillary measurements, including $\mathrm{PM}_{10}, \mathrm{PM}_{2.5}, \mathrm{PM}_{1}$ levels (Particulate Matter with aerodynamic diameter smaller than $10 \mu \mathrm{m}, 2.5 \mu \mathrm{m}$, and $1 \mu \mathrm{m}$ ), gases and black carbon concentrations and meteorological data, were performed during the measurement campaign. The analysis of specific periods (3 special cases) during the campaign revealed that road traffic was a significant source of $\mathrm{NH}_{3}$. However, its effect was more evident at UB compared with $\mathrm{CC}$ where it was masked given the high levels of $\mathrm{NH}_{3}$ from non-traffic sources measured in the old city. The relationship between $\mathrm{SO}_{4}^{2-}$ daily concentrations and gas-fraction ammonia $\left(\mathrm{NH}_{3} /\left(\mathrm{NH}_{3}+\mathrm{NH}_{4}^{+}\right)\right)$revealed that
\end{abstract}

the gas-to-particle phase partitioning (volatilization or ammonium salts formation) also played an important role in the evolution of $\mathrm{NH}_{3}$ concentration in summer in Barcelona.

\section{Introduction}

Atmospheric ammonia $\left(\mathrm{NH}_{3}\right)$ is among the most abundant nitrogen compounds in the atmosphere and it plays an important role in the neutralization of atmospheric acids to form ammonium salts, preferentially ammonium sulfate $\left(\left(\mathrm{NH}_{4}\right)_{2} \mathrm{SO}_{4}\right)$ and ammonium bisulfate $\left(\mathrm{NH}_{4} \mathrm{HSO}_{4}\right)$ from sulfuric acid. Excess $\mathrm{NH}_{3}$ is then available to form ammonium nitrate $\left(\mathrm{NH}_{4} \mathrm{NO}_{3}\right)$ from nitric acid or ammonium chloride $\left(\mathrm{NH}_{4} \mathrm{Cl}\right)$ from hydrochloric acid.

The formed ammonium salts are relatively stable particles with a longer lifetime (1-15 days, Sheppard et al., 2011; Aneja et al., 2000) compared with gaseous $\mathrm{NH}_{3}$ which is quickly dry deposited relatively close to the sources (Fowler et al., 1998; Phillips et al., 2004; Clarisse et al., 2009) thus allowing the long range transport of the acidic pollutants to remote areas (Aneja et al., 2000). For example, Ianniello et al. (2011) related the high concentrations of fine ammonium aerosols observed in Beijing to the impact of regional sources from areas with high concentrations of primary precursors (such as $\mathrm{NH}_{3}, \mathrm{SO}_{2}$, and $\mathrm{NO}_{\mathrm{x}}$ ).

One of the main concerns is related with the input of reactive nitrogen species to the terrestrial ecosystems and marine environments by nitrogen $(\mathrm{N})$ deposition leading to possible eutrophication and acidification of the ecosystem with changes in animal and plant populations and degradation of 
water and habitat quality (Flechard et al., 2011). Deposition of reactive $\mathrm{N}$ may be either wet when $\mathrm{NH}_{4}^{+}$particles are washed out in precipitation or dry when $\mathrm{NH}_{3}$ is directly deposited without chemical transformations (Sheppard et al., 2011; Phillips et al., 2004). High levels of ambient $\mathrm{NH}_{3}$ may cause adverse health effects by formation of fine particulate matter $\left(\mathrm{PM}_{1}\right.$ and $\mathrm{PM}_{2.5}$ ) (Erisman and Sutton, 2008; Brunekreef and Holgate, 2002; Ellis et al., 2011). Moreover, fine ammonium aerosols have strong environmental impacts being very effective in scattering visible light thus affecting visibility and radiation budget of the Earth-atmosphere system (e.g. Barthelmie and Pryor, 1998; Langridge et al., 2012).

It is widely recognized that the reactive nitrogen available to the ecosystem has increased dramatically over the past $50 \mathrm{yr}$ since humans in the early 20th century started to convert unreactive gaseous $\mathrm{N}_{2}$ into $\mathrm{NH}_{3}$ as a basis for fertilizers used for food production (Van Der Hoek, 1998; Sutton et al., 1993; Erisman et al., 2007, 2008; Erisman and Sutton, 2008). Overall, more than $80 \%$ of the chemical production of $\mathrm{NH}_{3}$ is used to produce fertilizer in the forms of ammonium nitrate, urea, and so on (Erisman et al., 2007). As a whole, agriculture is estimated to contribute for $94 \%$ to the total $\mathrm{NH}_{3}$ emission in Europe with livestock being the largest category in its emission inventory (EEA Technical Report, 2011). As a result, the scale of the environmental effects of $\mathrm{NH}_{3}$ emissions extended over the years from a few hotspots to the whole of Europe (Erisman and Sutton, 2008).

Other sources of $\mathrm{NH}_{3}$ include natural sources such as soil, oceans, vegetation, animal excreta, biomass burning, or anthropogenic sources such as industries (mainly manufacture of $\mathrm{NH}_{3}$ and $\mathrm{N}$ containing fertilizers), coal burning, power generation, sewage systems, wastes, human breath, sweat and smoking, and vehicle emissions (Sutton et al., 2000; Zhao et al., 2012). Globally these sources form a minor part of the emissions but they might be relevant locally playing the greater role in $\mathrm{NH}_{3}$ emissions. At urban level for example there is a growing concern related with the emissions of $\mathrm{NH}_{3}$ after the introduction of gasoline-powered vehicles equipped with three-way catalytic converters (Cape et al., 2004; Heeb et al., 2006) and diesel-powered vehicles adopting selective catalytic reduction (SCR) system (Kean et al., 2009). In the first case, $\mathrm{NH}_{3}$ is the product of $\mathrm{NO}$ reduction on the catalyst surface which, beyond the formation of molecular $\mathrm{N}_{2}$, leads to $\mathrm{NH}_{3}$ in motor vehicle exhaust. In the second case $\mathrm{NH}_{3}$ is used as reagent and supplied to the catalyst system by the injection of urea into the exhaust which then undergoes thermal decomposition and hydrolysis into $\mathrm{NH}_{3}$.

Many studies have been carried out to determine the $\mathrm{NH}_{3}$ emission factors from vehicles under different driving conditions by means of tunnel or dynamometer experiments showing the increased $\mathrm{NH}_{3}$ emissions from catalyzed vehicles (e.g. Moeckli et al., 1996; Fraser and Cass, 1998; Kean and Harley, 2000; Durbin et al., 2004; Burgard et al., 2006; Heeb et al., 2008; Kean et al., 2009). Contextually, measurements of ambient $\mathrm{NH}_{3}$ concentrations at urban level have been recently presented in many publications (Nowak et al., 2002; Perrino et al., 2002; Bari et al., 2003; Lin et al., 2006; Edgerton et al., 2007; Saylor et al., 2010; Nowak et al., 2010; Ianniello et al., 2010; Meng et al., 2011; Gong et al., 2011, among others).

These studies agreed with the fact that the concentrations and evolution of ambient $\mathrm{NH}_{3}$ at urban level were influenced by traffic emissions together with other important factors such as temperature changes (mainly seasonally), wind speed or direction, boundary layer deep and mixing, other local or regional $\mathrm{NH}_{3}$ emissions, dry deposition, and gas-to-particle partitioning. These factors may mask in some cases the effect of vehicle emissions on the measured $\mathrm{NH}_{3}$ concentrations. For example Meng et al. (2011) and Gong et al. (2011) measured $\mathrm{NH}_{3}$ concentrations in the urban areas of Beijing (annual averages between 18.5-23.5 ppb) and Houston (2.4 ppb in winter and $3.1 \mathrm{ppb}$ in summer), respectively, showing that correlations between $\mathrm{NH}_{3}$ concentrations and traffic tracers, such as $\mathrm{CO}$ and/or $\mathrm{NO}_{\mathrm{x}}$, were observed in winter but not in summer thus suggesting that other non-traffic sources became more important during the warm season (i.e. variations in local or regional emission sources, changes in vehicular catalytic converter performance, $\mathrm{NH}_{3}$ emissions from dew evaporation with increasing temperature in summer or natural release of $\mathrm{NH}_{3}$ from vegetation and soil through photosynthetic processes). Perrino et al. (2002) also identified vehicles as an important source of $\mathrm{NH}_{3}$ at many traffic sites in Rome (mean $\mathrm{NH}_{3}$ concentrations between $13.5 \mu \mathrm{g} \mathrm{m}^{-3}$ and $21.6 \mu \mathrm{g} \mathrm{m}^{-3}$ ) with higher $\mathrm{NH}_{3} / \mathrm{CO}$ ratio in summer compared with winter as a consequence of the evaporation of $\mathrm{NH}_{3}$ from particulates and from various non-traffic sources present in the selected urban area. Ianniello et al. (2010) compared the concentrations of $\mathrm{NH}_{3}$ measured in Beijing $\left(5.47 \mu \mathrm{g} \mathrm{m}^{-3}\right.$ in winter and $25.39 \mu \mathrm{g} \mathrm{m}^{-3}$ in summer) with $\mathrm{NO}_{\mathrm{x}}, \mathrm{CO}$ and $\mathrm{PM}_{2.5}$ and concluded that traffic was an important source of $\mathrm{NH}_{3}$. Nevertheless, the mean $\mathrm{NH}_{3}$ concentration was around five times higher in summer than in winter likely due to agricultural emissions enhanced under higher atmospheric temperatures (Ianniello et al., 2010). Saylor et al. (2010) analyzed the weekday versus weekend differences in composite hourly mean diurnal profiles of $\mathrm{NH}_{3}$ at an urban site (Atlanta) during July-December 2007 (mean $\mathrm{NH}_{3}$ at urban site: $1.3 \mathrm{ppb}$ ) and concluded that mobile sources had a measurable but relatively small impact on $\mathrm{NH}_{3}$ indicating the interaction of local $\mathrm{NH}_{3}$ emissions and dry deposition with the evolution of the diurnal and nocturnal boundary layer as concomitant important phenomenon affecting the concentrations of $\mathrm{NH}_{3}$.

Concomitance of different $\mathrm{NH}_{3}$ sources was also presented by Nowak et al. (2006) which showed that the diurnal cycles of $\mathrm{NH}_{3}$ measured at an urban site in Atlanta (from 0.4 to $13 \mathrm{ppb} \mathrm{NH}_{3}$ ) in summer presented a morning peak related with the rush hours and an afternoon peak related with non-traffic sources such as $\mathrm{NH}_{3}$ emissions from soil or $\mathrm{NH}_{3}$ 
release from secondary nitrate particle volatilization. Similarly, Lin et al. (2006) and Bari et al. (2003) associated the summer increase in the concentrations of $\mathrm{NH}_{3}$ measured at urban sites in Central Taiwan (annual mean $8.5 \mu \mathrm{g} \mathrm{m}^{-3}$ ) and New York (3-5 $\mu \mathrm{g} \mathrm{m}^{-3}$ ), respectively, with the higher volatility of $\mathrm{NH}_{4} \mathrm{NO}_{3}$ particulate under typical summer temperatures. Some of these studies also reported significant positive differences in $\mathrm{NH}_{3}$ levels between traffic and urban background stations (Perrino et al., 2002) or between urban and rural stations (Meng et al., 2011; Edgerton et al., 2007; Perrino et al., 2002) thus confirming traffic and human activities as potentially important sources of $\mathrm{NH}_{3}$ at urban levels.

As a consequence of the difficulties in distinguishing between the different $\mathrm{NH}_{3}$ sources, $\mathrm{NH}_{3}$ emissions from engines and vehicles are not yet regulated. Nevertheless, $\mathrm{NH}_{3}$ is listed as a toxic air pollutant by the EU and emission ceilings are defined for each member state (EC, 2001). In Spain a new regulation has been implemented on 28 January 2011 (Royal Decree 102/2011) establishing the requirement to measure $\mathrm{NH}_{3}$ levels at five rural background stations covering the country and at one traffic site in cities with more than 500000 inhabitants. At European level the critical level for $\mathrm{NH}_{3}$ has been established in $8 \mu \mathrm{g} \mathrm{m}^{-3}$ as an annual mean (Air Quality Guidelines for Europe, 2000) although recent studies reported important effects on vegetation when $\mathrm{NH}_{3}$ levels are above $3 \mu \mathrm{g} \mathrm{m}^{-3}$ (Cape et al., 2009).

In this study we present the results of a measurement campaign performed in Barcelona (NE Spain) between May and September 2011 and mainly aimed: (a) to study the differences in the concentrations and dynamics of ambient $\mathrm{NH}_{3}$ at two urban sites with different characteristics in term of $\mathrm{NH}_{3}$ emission sources; (b) to asses major sources and sinks affecting the daily evolution of $\mathrm{NH}_{3}$ concentrations; (c) to understand the reasons for the high concentrations of secondary sulfate particles usually observed in Barcelona in summer compared with other urban and industrial sites across Spain (Querol et al., 2008). With this aim, the differences in $\mathrm{NH}_{3}$ concentrations and daily evolutions at the two selected sites in Barcelona (one in the historical city centre and one in a traffic-influenced urban background area) will be presented and discussed.

\section{Methods}

\subsection{Sampling sites}

The measurements of $\mathrm{NH}_{3}$ and ancillary data were performed at two measurement sites in the city of Barcelona (NE Spain) (Fig. 1). The first site (UB; $41^{\circ} 23^{\prime} 24.01^{\prime \prime} \mathrm{N}$ $02^{\circ} 06^{\prime} 58.06^{\prime \prime} \mathrm{E}$; $68 \mathrm{~m}$ a.s.l., $1 \mathrm{~m}$ a.g.l.) is a urban background site influenced by vehicular emissions from one of the main avenues of the city (Diagonal Avenue) located at a distance of around $300 \mathrm{~m}$ with a traffic density of 132000 vehicles per day (around $60 \%$ diesel in vehicle fleet; Council of

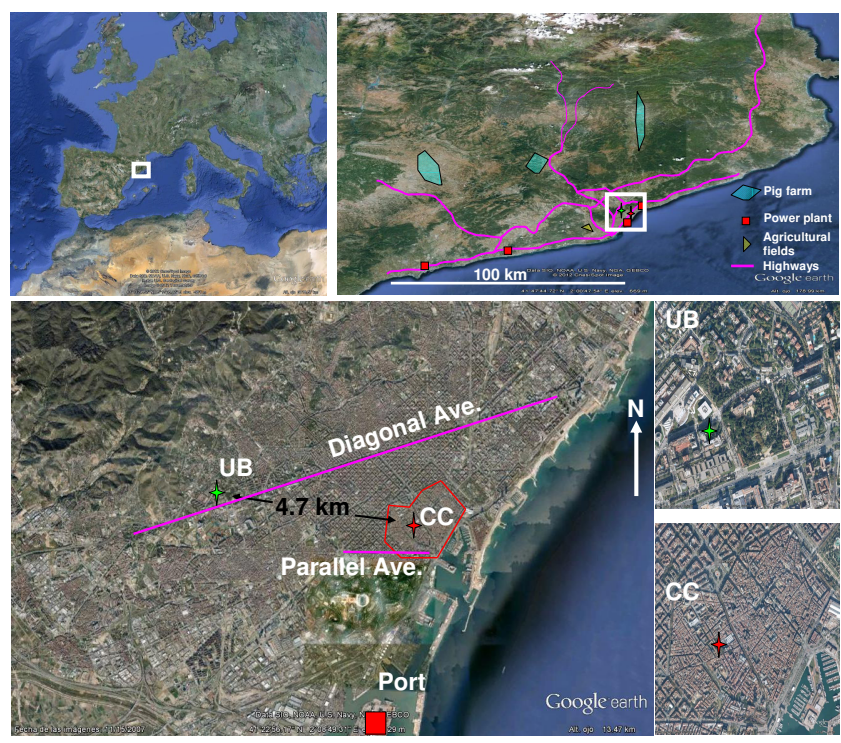

Fig. 1. Location of the two measurement sites in Barcelona (NE Spain): UB (traffic-influenced urban background) and CC (historical city center). Type and location of potential sources of $\mathrm{NH}_{3}$ are reported in the figure.

Barcelona, Serveis de Mobilitat, 2009). The second measurement site (CC; $41^{\circ} 22^{\prime} 58.18^{\prime \prime} \mathrm{N} 02^{\circ} 10^{\prime} 08.59^{\prime \prime} \mathrm{E}$; $30 \mathrm{~m}$ a.s.1.) is placed on the roof of a $20 \mathrm{~m}$ height building in the densely populated historic city centre of Barcelona, less influenced by traffic emissions but dense with commercial activities (markets, restaurants, pubs and so on) and people wandering around the old city and mainly in summer when tourism is high. The two measurement sites were around $4.7 \mathrm{~km}$ apart. The main possible important sources of $\mathrm{NH}_{3}$ in the area under study included major highways and roads, pig farms, agricultural fields, and power plants. Figure 1 shows that the majority of these sources were located relatively far from Barcelona with the exception of two power plants located at around $5 \mathrm{~km}$ south and $10 \mathrm{~km}$ north-east the measurement sites and some major roads which surrounded the sites. Main agricultural fields, mainly vegetable groves and orchards, were located $25 \mathrm{~km}$ west the measurement stations.

\subsection{Measurements}

The measurements of $\mathrm{NH}_{3}$ were supplemented with a set of ancillary hourly measurements of gaseous pollutants $\left(\mathrm{NO}_{2}\right.$, $\left.\mathrm{NO}, \mathrm{O}_{3}, \mathrm{SO}_{2}\right)$, particulate matter $\left(\mathrm{PM}_{\mathrm{x}}\right)$ and black carbon (BC) concentrations, meteorological data (wind speed and direction, temperature, humidity, solar radiation and pressure) and daily mean concentrations of secondary inorganic aerosols $\left(\mathrm{NH}_{4}^{+}, \mathrm{SO}_{4}^{2-}\right.$ and $\left.\mathrm{NO}_{3}^{-}\right)$. Measurements were performed at UB from 6 May to 7 September 2011 and at CC from 13 May up to 28 June 2011. Not all the parameters were monitored at both sites. The concentrations of $\mathrm{NH}_{3}, \mathrm{BC}$ and meteorological data were measured at both measurement 
sites while the concentrations of $\mathrm{PM}_{\mathrm{x}}\left(\mathrm{PM}_{10}, \mathrm{PM}_{2.5}, \mathrm{PM}_{1}\right)$ and gaseous pollutants were measured only at UB site.

\subsection{1 $\mathrm{NH}_{3}$ measurements}

On-line measurements of gas-phase $\mathrm{NH}_{3}$ on a 1-min base were performed by means of two gas-phase- $\mathrm{NH}_{3}$-measuring instruments (AiRRmonia; http://www.mechatronics.nl) (Erisman et al., 2001; Wyers et al., 1993). The instrument has the potential to detect $\mathrm{NH}_{3}$ concentrations from 0.1 up to $100 \mu \mathrm{g} \mathrm{m}^{-3}$ in real time and has shown good performances during a field inter-comparison campaign in Scotland (von Bobrutzki et al., 2010).

The instrument uses a gas-permeable PTFE (polytetrafluoroethylene) membrane to selectively permeate the $\mathrm{NH}_{3}$ from the air flow $\left(11 \mathrm{~min}^{-1}\right)$ into the stripping solution where $\mathrm{NH}_{3}$ is converted to $\mathrm{NH}_{4}^{+}$. Otjes and Erisman (1999) showed that the ammonium contained in ammonium nitrate and sulfate particles is not retained by the sampling membrane and less than $1 \%$ and $3 \%$ of $\left(\mathrm{NH}_{4}\right)_{2} \mathrm{SO}_{4}$ and $\mathrm{NH}_{4} \mathrm{NO}_{3}$, respectively, are captured. The $\mathrm{pH}$ of the stripping solution is raised by addition of sodium hydroxide $(\mathrm{NaOH})$ to form molecular $\mathrm{NH}_{3}$ which is transferred through a second PTFE membrane in the detector block into a stream of pure deionised water where the $\mathrm{NH}_{3}$ is reverted to $\mathrm{NH}_{4}^{+}$. The $\mathrm{NH}_{4}^{+}$concentrations are then determined by a conductivity measurement of the water and calibration is made using aqueous $\mathrm{NH}_{4}^{+}$standard solutions. During the measurement campaign both AiRRmonias were calibrated approximately once per week (Slanina et al., 2001).

\subsubsection{Ancillary measurements}

Hourly levels of $\mathrm{PM}_{10}, \mathrm{PM}_{2.5}$ and $\mathrm{PM}_{1}$ at UB were continuously measured by means of a laser-spectrometer dust monitor (Grimm Labortechnik GmbH \& Co. KG; model 180). Then the levels of PM were corrected by means of standard $24 \mathrm{~h}$ PM gravimetric measurements performed twice per week with high volume samplers (DIGITEL and MCV at $\left.30 \mathrm{~m}^{3} \mathrm{~h}^{-1}\right)$ with appropriate $\left(\mathrm{PM}_{10}, \mathrm{PM}_{2.5}\right.$ and $\left.\mathrm{PM}_{1}\right)$ cut-off inlets.

The measurements of the ambient concentrations of black carbon (BC) were performed at UB by means of a MAAP instrument (Multi Angle Absorption Photometer, model 5012, Thermo) and at CC by using an aethalometer (microAeth Model AE51, Magee Scientific). With the MAAP the content of BC were continuously determined by simultaneously measuring the optical absorption and scattering of light by the particles collected on the filter tape (Müller et al., 2011). The Magee aethalometer is a small and portable monitor with a Teflon coated borosilicate glass fibre filter where particles were captured. The aethalometer detects changes in the optical absorption of the light transmitted through the filter and calculates the BC load. The filter inside the aethalometer was replaced every day in order to prevent saturation.

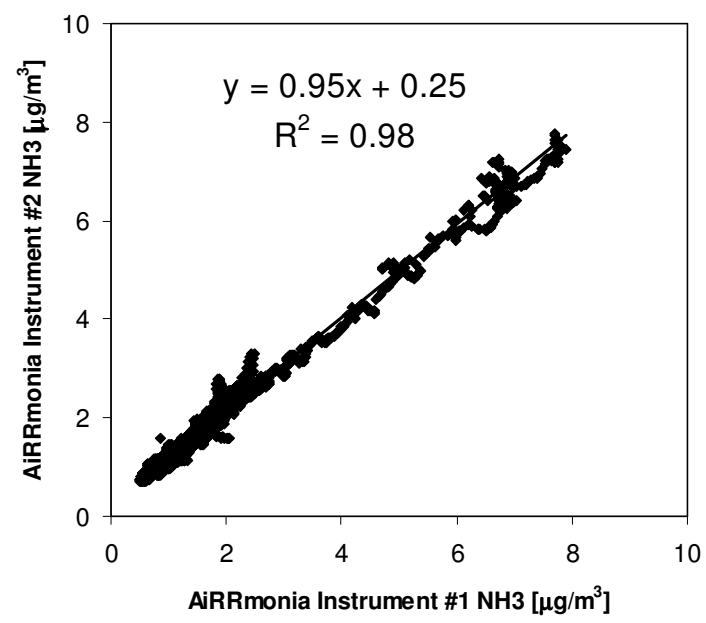

Fig. 2. Intercomparison between the two AiRRmonia instruments deployed during the measurement campaign. Site used for the intercomparison: UB. Temporal resolution: $1 \mathrm{~min}$.

Finally, conventional analyzers were used for measurements of levels of gaseous pollutants at UB (Thermo Scientific, Model 42i for $\mathrm{NO}_{\mathrm{x}}$ and MCV S.A., model 48AUX for $\mathrm{O}_{3}$ ) and meteorological data were collected at both UB and $\mathrm{CC}$ by means of meteorological stations.

\section{Results}

\subsection{AiRRmonia intercomparison}

The two AiRRmonia instruments deployed at UB and CC sites were intercompared before the measurement campaign in order to assure the quality of the intercomparison between the $\mathrm{NH}_{3}$ concentrations measured at both measurement sites. Figure 2 shows the results of the intercomparison performed between 6 and 11 May at UB site based on 1-min resolution data.

As reported in the Fig. 2 the correlation between the two instruments was very good with a coefficient of determination $R^{2}$ of 0.98 and a small bias of around $4 \%$.

\subsection{General features}

Figure $\mathrm{S} 1$ (in the Supplement) shows the time series of $\mathrm{NH}_{3}$, $\mathrm{BC}, \mathrm{PM}_{1}, \mathrm{PM}_{2.5-10}$ and gaseous pollutant concentrations and meteorological data available at CC and UB measurement stations. The black dashed boxes named sc1-sc3 in the Fig. S1 highlight periods considered as special cases and discussed in detail in the following paragraphs.

As reported in Fig. S1 some measurements were sporadically not available because of technical problems. This is the case of $\mathrm{NH}_{3}$ at UB from 19 May to 9 June and from 12 to 15 August, BC at UB after 20 August, gases concentrations 
Table 1. Statistics on available measurements performed at the urban background (UB) and historical city centre (CC) measurement stations. Statistics at UB were also reported for the same sampling period of CC station (13 May-28 June).

\begin{tabular}{|c|c|c|c|c|c|c|c|c|c|}
\hline station & & & & & & & & & \\
\hline $\begin{array}{l}\text { UB } \\
(06 / 05-07 / 09) \\
2967 \mathrm{~h}\end{array}$ & Unit & Availability & Mean & SD & 25 th perc. & 50th perc. & 75th perc. & $\min$ & $\max$ \\
\hline $\mathrm{NH}_{3}$ & $\mu \mathrm{g} \mathrm{m}^{-3}$ & 2157 h $(73 \%)$ & 2.2 & 1.0 & 1.4 & 1.9 & 2.6 & 0.2 & 10.6 \\
\hline NO & $\mu \mathrm{g} \mathrm{m}^{-3}$ & 2791 h (94 \%) & 5.1 & 10.4 & 1.5 & 3.0 & 5.0 & 1.0 & 211.0 \\
\hline $\mathrm{NO}_{2}$ & $\mu \mathrm{g} \mathrm{m}^{-3}$ & 2791 h (94 \%) & 23.9 & 16.2 & 13.0 & 19.5 & 30.0 & 1.0 & 138.5 \\
\hline $\mathrm{O}_{3}$ & $\mu \mathrm{g} \mathrm{m}^{-3}$ & 2773 h (93\%) & 62.7 & 25.6 & 46.0 & 63.5 & 79.5 & 1.0 & 194.5 \\
\hline $\mathrm{SO}_{2}$ & $\mu \mathrm{g} \mathrm{m}^{-3}$ & 2791 h (94 \%) & 2.2 & 1.9 & 1.0 & 1.5 & 2.5 & 1.0 & 27.5 \\
\hline $\mathrm{BC}$ & $\mathrm{ng} \mathrm{m}^{-3}$ & 2394 h ( $81 \%)$ & 1554 & 1158 & 870 & 1231 & 1870 & -22 & 11153 \\
\hline $\mathrm{PM}_{10}$ & $\mu \mathrm{g} \mathrm{m}^{-3}$ & 2853 h (96\%) & 25.2 & 8.2 & 19.2 & 23.9 & 29.8 & 10.8 & 97.9 \\
\hline $\mathrm{PM}_{2.5}$ & $\mu \mathrm{g} \mathrm{m}^{-3}$ & 2853 h (96\%) & 19.1 & 7.1 & 13.7 & 17.7 & 22.8 & 7.4 & 63.5 \\
\hline $\mathrm{PM}_{1}$ & $\mu \mathrm{g} \mathrm{m}^{-3}$ & $2853 \mathrm{~h}(96 \%)$ & 13.6 & 5.9 & 9.1 & 12.5 & 16.7 & 4.2 & 44.6 \\
\hline$T$ & ${ }^{\circ} \mathrm{C}$ & 2611 h (88\%) & 23.7 & 3.1 & 21.7 & 23.7 & 25.9 & 14.1 & 34.4 \\
\hline RH & $\%$ & $2611 \mathrm{~h}(88 \%)$ & 73.4 & 12.6 & 65.7 & 75.0 & 83.2 & 34.0 & 100.0 \\
\hline Prec & $\mathrm{mm}$ & 2611 h (88\%) & 0.01 & 0.1 & 0.00 & 0.00 & 0.00 & 0.00 & 3.43 \\
\hline Wind speed & $\mathrm{ms}^{-1}$ & 2611 h ( $88 \%)$ & 1.9 & 1.1 & 1.0 & 1.7 & 2.5 & 0.2 & 6.8 \\
\hline Sol Rad & $\mathrm{W} \mathrm{m}^{-2}$ & $2611 \mathrm{~h}(88 \%)$ & 252.9 & 314.8 & 0 & 75 & 488 & 0 & 1035 \\
\hline \multicolumn{10}{|l|}{$\begin{array}{l}\mathrm{CC} \\
(13 / 05-28 / 06) \\
1100 \mathrm{~h}\end{array}$} \\
\hline $\mathrm{NH}_{3}$ & $\mu \mathrm{g} \mathrm{m}^{-3}$ & 978 h (89\%) & 5.6 & 2.1 & 4.2 & 5.2 & 6.5 & 1.8 & 16.2 \\
\hline $\mathrm{BC}$ & $\mathrm{ng} \mathrm{m}^{-3}$ & 899 h $(82 \%)$ & 1190 & 1059 & 524 & 867 & 1552 & -20 & 7383 \\
\hline$T$ & ${ }^{\circ} \mathrm{C}$ & $1100 \mathrm{~h}(100 \%)$ & 21.6 & 3.2 & 19.2 & 21.5 & 23.8 & 14.3 & 30.9 \\
\hline RH & $\%$ & $1100 \mathrm{~h}(100 \%)$ & 65.1 & 13.9 & 56.0 & 66.0 & 76.0 & 26.0 & 94.0 \\
\hline Prec & $\mathrm{mm}$ & $1100 \mathrm{~h}(100 \%)$ & 0.1 & 0.8 & 0.0 & 0.0 & 0.0 & 0.0 & 14.4 \\
\hline Wind speed & $\mathrm{ms}^{-1}$ & $1100 \mathrm{~h}(100 \%)$ & 2.1 & 1.0 & 1.3 & 2.0 & 2.8 & 0.1 & 5.1 \\
\hline Solar rad. & $\mathrm{W} \mathrm{m}^{-2}$ & $1100 \mathrm{~h}(100 \%)$ & 284 & 335 & 0 & 101 & 602 & 0 & 964 \\
\hline \multicolumn{10}{|l|}{$\begin{array}{l}\text { UB } \\
(13 / 05-28 / 06) \\
1100 \mathrm{~h}\end{array}$} \\
\hline $\mathrm{NH}_{3}$ & $\mu \mathrm{g} \mathrm{m}^{-3}$ & $526 \mathrm{~h}(48 \%)$ & 2.6 & 1.1 & 1.8 & 2.3 & 3.2 & 0.5 & 10.6 \\
\hline NO & $\mu \mathrm{g} \mathrm{m}^{-3}$ & $930 \mathrm{~h}(85 \%)$ & 4.9 & 11.4 & 1.0 & 2.0 & 4.5 & 1.0 & 211.0 \\
\hline $\mathrm{NO}_{2}$ & $\mu \mathrm{g} \mathrm{m}^{-3}$ & 930 h (85\%) & 25.6 & 17.6 & 13.5 & 21.5 & 33.0 & 1.0 & 138.5 \\
\hline $\mathrm{O}_{3}$ & $\mu \mathrm{g} \mathrm{m}^{-3}$ & $930 \mathrm{~h}(85 \%)$ & 66.9 & 25.4 & 51.5 & 68.0 & 83.0 & 6.0 & 132.0 \\
\hline $\mathrm{SO}_{2}$ & $\mu \mathrm{g} \mathrm{m}^{-3}$ & $930 \mathrm{~h}(85 \%)$ & 2.9 & 2.1 & 1.5 & 2 & 3.5 & 1 & 17.5 \\
\hline $\mathrm{BC}$ & $\mathrm{ng} \mathrm{m}^{-3}$ & 1047 h $(95 \%)$ & 1665 & 1283 & 904 & 1293 & 2010 & -22 & 11153 \\
\hline $\mathrm{PM}_{10}$ & $\mu \mathrm{g} \mathrm{m}^{-3}$ & $1100 \mathrm{~h}(100 \%)$ & 23.4 & 6.4 & 18.6 & 22.6 & 27.0 & 12.0 & 54.1 \\
\hline $\mathrm{PM}_{2.5}$ & $\mu \mathrm{g} \mathrm{m}^{-3}$ & $1100 \mathrm{~h}(100 \%)$ & 18.3 & 6.0 & 13.8 & 17.1 & 21.4 & 9.1 & 48.7 \\
\hline $\mathrm{PM}_{1}$ & $\mu \mathrm{g} \mathrm{m}^{-3}$ & $1100 \mathrm{~h}(100 \%)$ & 13.4 & 5.3 & 9.4 & 12.2 & 16.3 & 6.0 & 40.9 \\
\hline$T$ & ${ }^{\circ} \mathrm{C}$ & 907 h $(83 \%)$ & 20.6 & 3.2 & 18.1 & 20.4 & 22.5 & 14.1 & 30.3 \\
\hline RH & $\%$ & $907 \mathrm{~h}(83 \%)$ & 69.9 & 15.2 & 59.2 & 71.8 & 81.1 & 27.0 & 98.5 \\
\hline Prec & $\mathrm{mm}$ & $907 \mathrm{~h}(83 \%)$ & 0.0 & 0.1 & 0.0 & 0.0 & 0.0 & 0.0 & 3.3 \\
\hline Wind speed & $\mathrm{ms}^{-1}$ & 907 h (83\%) & 1.9 & 1.2 & 1.0 & 1.7 & 2.4 & 0.2 & 6.7 \\
\hline Sol Rad & $\mathrm{W} \mathrm{m}^{-2}$ & 907 h (83\%) & 266.7 & 328.7 & 0.0 & 75.8 & 490.8 & 0.0 & 1034.7 \\
\hline
\end{tabular}




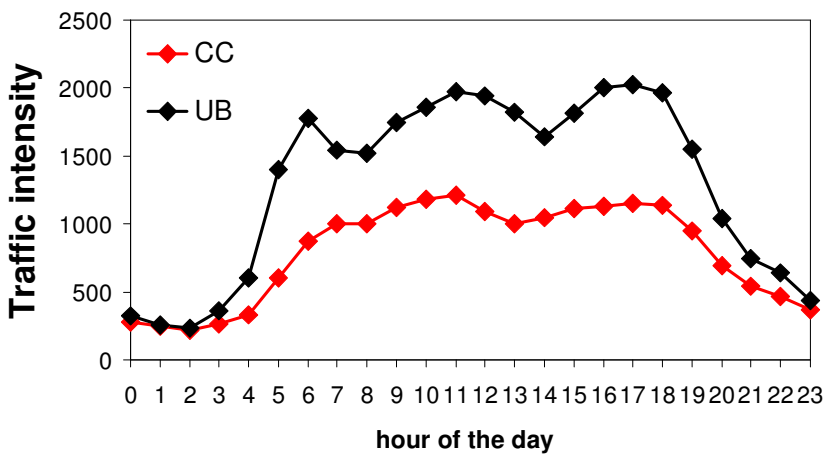

Fig. 3. Mean daily cycles of number of vehicles at UB (Diagonal Ave.) and CC (Parallel Ave.) measurement sites.

and meteorological data at UB from 22 to 27 June and from 20 June to 5 July, respectively.

Table 1 shows the statistics for the measurements performed at both sites reporting sampling periods, percentage of available measurements on hourly base, means, standard deviations, 25th, 50th (i.e. medians) and 75th percentiles, minimum and maximum values. Table 1 also reports the statistics for the UB station averaged over the CC sampling period, i.e. from 13 May to 28 June.

On average the levels of $\mathrm{NH}_{3}$ at $\mathrm{CC}$ station were higher compared with UB. Mean $\mathrm{NH}_{3}$ levels of $5.6 \pm 2.1 \mu \mathrm{g} \mathrm{m}^{-3}$ $(7.5 \pm 2.8 \mathrm{ppbv})$ and $2.2 \pm 1.0 \mu \mathrm{g} \mathrm{m}^{-3}(2.9 \pm 1.3 \mathrm{ppbv})$ were measured at CC and UB, respectively. Over the same CC sampling period (13 May-28 June) the mean $\mathrm{NH}_{3}$ concentration at UB was $2.6 \pm 1.1 \mu \mathrm{g} \mathrm{m}^{-3}$, close to the mean value obtained by averaging all the $\mathrm{NH}_{3}$ data available for UB station. The minimum and maximum $\mathrm{NH}_{3}$ concentrations at $\mathrm{CC}$ station on hourly base were $1.8 \mu \mathrm{g} \mathrm{m}^{-3}$ (2.4 ppbv) and $16.2 \mu \mathrm{g} \mathrm{m}^{-3}$ (21.6 ppbv), respectively, while $0.2 \mu \mathrm{g} \mathrm{m}^{-3}$ ( $0.27 \mathrm{ppbv}$ ) (or $0.5 \mu \mathrm{g} \mathrm{m}^{-3}$ over the CC sampling period; Table 1 ) and $10.6 \mu \mathrm{g} \mathrm{m}^{-3}$ (14.1 ppbv) were respectively measured at UB site. The Black Carbon (BC) concentration at UB $\left(1665 \pm 1158 \mathrm{ng} \mathrm{m}^{-3}\right.$ over the same CC sampling period) was higher compared with the mean $\mathrm{BC}$ concentration registered at $\mathrm{CC}\left(1190 \pm 1059 \mathrm{ng} \mathrm{m}^{-3}\right)$ where higher $\mathrm{NH}_{3}$ concentrations were observed. Higher BC concentrations at UB were consistent with the higher number of vehicles registered on average at UB site compared with CC (Fig. 3). Traffic density data were collected concurrently to the measurement campaign by means of induction loops embedded in the road pavement and the closest induction loops to the measurement sites were used as reference. Figure 3 shows that the mean number of vehicles traveling the Diagonal Avenue (close to the UB site) and the main avenue (Parallel Ave.) close to the CC site (Fig. 1) was high from around 05:00 to 19:00 GMT at both sites. However, the mean number of vehicles at UB was almost twice compared with CC. Thus, by comparing the CC and UB measurement sites in terms of number of vehicles and $\mathrm{BC}$ concentrations it can be deduceed that an important contribution to the higher $\mathrm{NH}_{3}$ concentrations measured at $\mathrm{CC}$ came from other sources than traffic. A measurement campaign with passive $\mathrm{NH}_{3}$ samplers performed at different sites in Barcelona (Reche et al., 2012) showed that humans, waste containers and sewage systems were potential important sources of $\mathrm{NH}_{3}$ in the historical city centre. These sources are especially dense in the old city where the population density is also high. Under high temperatures in summer these sources have the potential to increase the ambient levels of $\mathrm{NH}_{3}$ at $\mathrm{CC}$ well above the urban-background-traffic-influenced UB measurement station. Moreover, the urban design of the old city of Barcelona with narrow streets also favored the accumulation of $\mathrm{NH}_{3}$ preventing the dispersion of air pollutants. Finally, the fact that the lowest hourly $\mathrm{NH}_{3}$ concentration at $\mathrm{CC}$ was $1.8 \mu \mathrm{g} \mathrm{m}^{-3}$ also demonstrates the presence of a relatively high background of $\mathrm{NH}_{3}$ in the old city. The difference between the $\mathrm{NH}_{3}$ concentrations between both sites was around $3 \mu \mathrm{g} \mathrm{m}^{-3}$ (4 ppbv) which can be seen as the minimum mean contribution from non-traffic sources affecting CC site. Figure 4 reports the polar plots (source Openair; Carslaw and Ropkins, 2011) of the concentrations of $\mathrm{NH}_{3}$ measured at UB and CC sites. The Figure clearly shows that on average the highest concentrations of $\mathrm{NH}_{3}$ at $\mathrm{CC}\left(>6.0 \mu \mathrm{g} \mathrm{m}^{-3}\right)$ had a very local origin, being detected under low wind speeds $\left(<1 \mathrm{~m} \mathrm{~s}^{-1}\right)$, and that important concentrations of $\mathrm{NH}_{3}$ were transported from the north-west toward the $\mathrm{CC}$ site when wind speeds were higher $\left(>2 \mathrm{~m} \mathrm{~s}^{-1}\right)$. Conversely, at UB site the highest concentrations of $\mathrm{NH}_{3}\left(>2 \mu \mathrm{g} \mathrm{m}^{-3}\right)$ were detected when winds blew with high velocities from the south, i.e. from major roads and from the city centre, where the highest $\mathrm{NH}_{3}$ concentrations were measured. Thus, Fig. 4 shows that the major sources of $\mathrm{NH}_{3}$ in Barcelona were located within the city between the CC and UB sites thus suggesting a more local origin for the measured concentrations of $\mathrm{NH}_{3}$ at both sites. Moreover, the high difference observed for the $\mathrm{NH}_{3}$ concentrations measured at UB and CC also suggested a reduced contribution from regional $\mathrm{NH}_{3}$ sources.

The levels of $\mathrm{PM}_{10}, \mathrm{PM}_{2.5}$ and $\mathrm{PM}_{1}$ measured at UB were $25.2 \pm 8.2 \mu \mathrm{g} \mathrm{m}^{-3}, \quad 19.1 \pm 7.1 \mu \mathrm{g} \mathrm{m}^{-3}$ and $13.6 \pm 5.1 \mu \mathrm{g} \mathrm{m}^{-3}$, respectively, during the period 6 May7 September. Amato et al. (2009) reported concentrations of $\mathrm{PM}_{10}, \mathrm{PM}_{2.5}$ and $\mathrm{PM}_{1}$ of $40.3 \mu \mathrm{g} \mathrm{m}^{-3}, 27.7 \mu \mathrm{g} \mathrm{m}^{-3}$ and $17.3 \mu \mathrm{g} \mathrm{m}^{-3}$, respectively, during the period $2003-2007$ in Barcelona. The relatively low PM concentrations reported in this study were due to the atmospheric conditions typically observed in summer in the Western Mediterranean Basin (WMB) characterized by higher dispersion of pollutants in the atmosphere at a local scale due to higher planetary boundary layer heights and higher recirculation of air masses over the WMB (Jorba et al., 2011; Pey et al., 2008) thus leading to lower mean levels of PM in summer in Barcelona compared with the whole year.

The mean concentrations of $\mathrm{NO}, \mathrm{NO}_{2}, \mathrm{O}_{3}$ and $\mathrm{SO}_{2}$ during the UB measurement period (6 May-7 September) were 


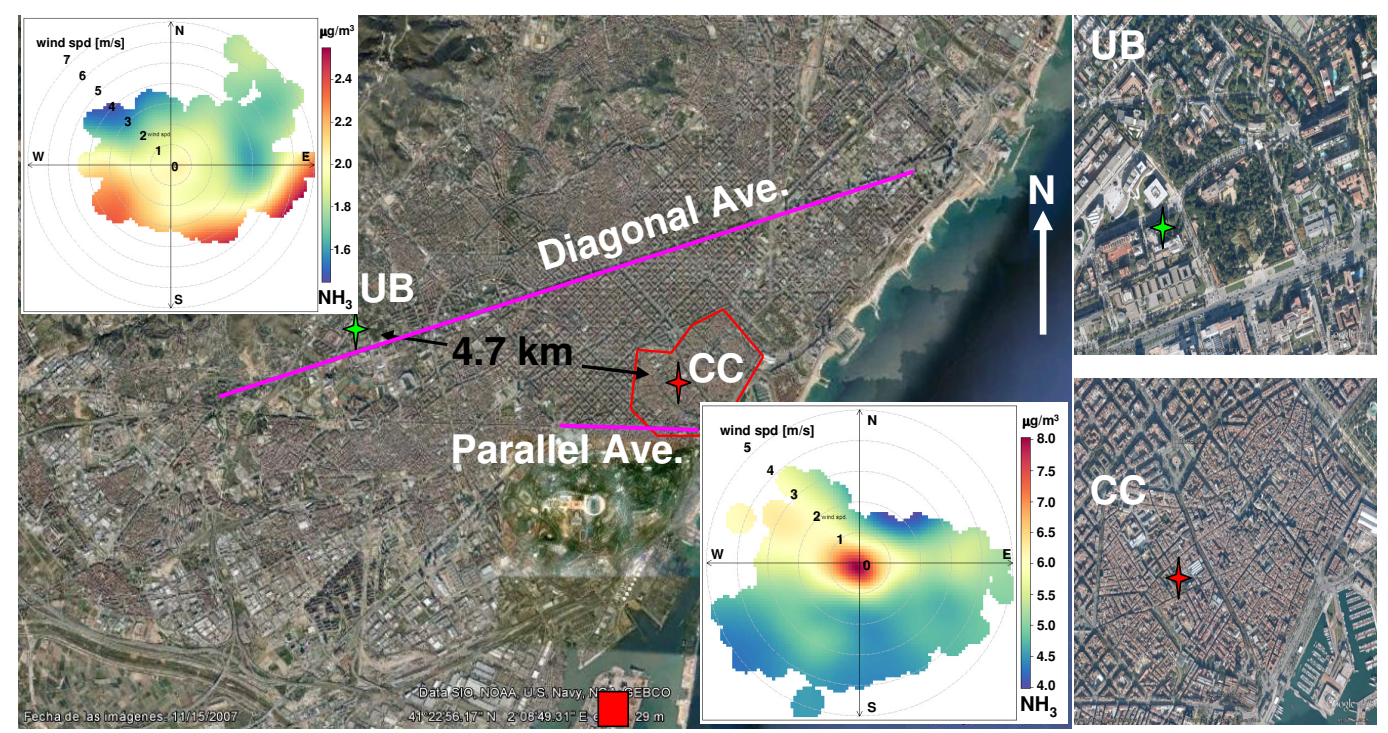

Fig. 4. Polar plots of the concentrations of $\mathrm{NH}_{3}$ measured at $\mathrm{UB}$ and $\mathrm{CC}$ sites.

Table 2. Coefficients of determination $\left(R^{2}\right)$ at UB measurement site. $R^{2}$ higher than 0.6 are highlighted in bold.

\begin{tabular}{|c|c|c|c|c|c|c|c|c|c|c|c|c|c|c|c|c|}
\hline $\begin{array}{l}R^{2} \mathrm{UB} \\
(24 \mathrm{~h} \text { base) }\end{array}$ & $\mathrm{NH}_{3}$ & NO & $\mathrm{NO}_{2}$ & $\mathrm{NO}_{\mathrm{x}}$ & $\mathrm{SO}_{2}$ & $\mathrm{SO}_{4}^{2-}$ & $\mathrm{NO}_{3}^{-}$ & $\mathrm{NH}_{4}^{+}$ & $\mathrm{BC}$ & $\mathrm{PM}_{1}$ & $\mathrm{PM}_{10}$ & $\mathrm{PM}_{2.5-10}$ & $T$ & RH & ws & wd \\
\hline $\mathrm{NH}_{3}$ & - & 0.15 & 0.15 & 0.16 & 0.04 & 0.02 & 0.06 & 0.00 & 0.20 & 0.01 & 0.05 & 0.12 & 0.17 & 0.24 & 0.04 & 0.01 \\
\hline $\mathrm{NO}$ & & - & 0.72 & 0.85 & 0.40 & 0.15 & 0.36 & 0.25 & 0.54 & 0.17 & 0.12 & 0.02 & 0.20 & 0.10 & 0.10 & 0.30 \\
\hline $\mathrm{NO}_{2}$ & & & - & 0.97 & 0.40 & 0.15 & 0.45 & 0.33 & 0.65 & 0.28 & 0.18 & 0.01 & 0.44 & 0.04 & 0.23 & 0.17 \\
\hline $\mathrm{NO}_{\mathrm{x}}$ & & & & - & 0.43 & 0.16 & 0.44 & 0.32 & 0.68 & 0.26 & 0.17 & 0.01 & 0.37 & 0.06 & 0.20 & 0.22 \\
\hline $\mathrm{SO}_{2}$ & & & & & - & 0.28 & 0.24 & 0.32 & 0.51 & 0.08 & 0.05 & 0.00 & 0.13 & 0.09 & 0.06 & 0.74 \\
\hline $\mathrm{SO}_{4}^{2-}$ & & & & & & - & 0.04 & 0.80 & 0.40 & 0.62 & 0.62 & 0.21 & 0.01 & 0.07 & 0.10 & 0.22 \\
\hline $\mathrm{NO}_{3}^{-}$ & & & & & & & - & 0.03 & 0.24 & 0.06 & 0.06 & 0.03 & 0.45 & 0.17 & 0.03 & 0.01 \\
\hline $\mathrm{NH}_{4}^{+}$ & & & & & & & & - & 0.42 & 0.76 & 0.60 & 0.09 & 0.02 & 0.14 & 0.17 & 0.21 \\
\hline $\mathrm{BC}^{4}$ & & & & & & & & & - & 0.48 & 0.40 & 0.07 & 0.06 & 0.02 & 0.45 & 0.36 \\
\hline $\mathrm{PM}_{1}$ & & & & & & & & & & - & 0.88 & 0.17 & 0.11 & 0.05 & 0.01 & 0.12 \\
\hline $\mathrm{PM}_{10}$ & & & & & & & & & & & - & 0.51 & 0.06 & 0.01 & 0.01 & 0.08 \\
\hline $\mathrm{PM}_{2.5-10}$ & & & & & & & & & & & & - & 0.00 & 0.07 & 0.12 & 0.00 \\
\hline$t$ & & & & & & & & & & & & & - & 0.24 & 0.00 & 0.03 \\
\hline RH & & & & & & & & & & & & & & - & 0.08 & 0.04 \\
\hline ws & & & & & & & & & & & & & & & - & 0.00 \\
\hline wd & & & & & & & & & & & & & & & & - \\
\hline
\end{tabular}

around $5,24,63,2 \mu \mathrm{g} \mathrm{m} \mathrm{m}^{-3}$, respectively, and the mean $T$, $\mathrm{RH}$, precipitation, solar radiation and wind speed were similar at both sites (Table 1). Relatively high mean temperatures around $22-24{ }^{\circ} \mathrm{C}$ were measured during the measurement campaign with relative humidity $(\mathrm{RH})$ around $73 \%$ and $65 \%$ at $\mathrm{UB}$ and $\mathrm{CC}$ respectively (the $\mathrm{RH}$ mean value at UB over the CC sampling period was $70 \%$ ). A slightly higher wind speed at $\mathrm{CC}\left(2.1 \mathrm{~m} \mathrm{~s}^{-1}\right)$ was observed compared with UB $\left(1.9 \mathrm{~m} \mathrm{~s}^{-1}\right)$. Differences in meteorological data between UB and CC were mainly due to the relative distance between the measurement sites (Fig. 1). The measurement period was on average sunny with sporadic rain events resulting in a total of $47 \mathrm{~h}(1.6 \%)$ at UB and $60 \mathrm{~h}(5.5 \%)$ at CC with mm of rain per hour ranging from 0.1 to around 14 (highest value registered at $\mathrm{CC}$ ).

Table 2 shows the coefficients of determination $\left(R^{2}\right)$ between the atmospheric components and parameters available for UB site where a larger and more complete dataset was collected compared with CC. The $R^{2}$ higher than 0.6 were highlighted in Table 2.

As expected high $R^{2}$ were observed between $\mathrm{NO}, \mathrm{NO}_{2}$, $\mathrm{NO}_{\mathrm{x}}$, and $\mathrm{BC}$, being these atmospheric components emitted mainly by passing vehicles. Interestingly, $\mathrm{SO}_{2}$ was the only variable which correlated with the direction of the wind due to the transport of $\mathrm{SO}_{2}$ from the port of Barcelona (Fig. 1) toward the UB site when the sea breeze was active. On average 
no correlations were observed between $\mathrm{NH}_{3}$ and temperature and/or relative humidity because both variables changed only little during the measurement campaign. Dependences of $\mathrm{NH}_{3}$ with $T$ and $\mathrm{RH}$ have been observed mainly by comparing winter and summer months when both atmospheric variables vary considerably (e.g. Reche et al., 2012). Secondary sulfates were strongly correlated with ammonium, $\mathrm{PM}_{1}$ and $\mathrm{PM}_{10}$ but not with the coarse $\mathrm{PM}$ mode $\left(\mathrm{PM}_{2.5-10}\right)$ thus suggesting a finer character of secondary sulfate particles which were present mainly in the form of ammonium sulfates.

As previously observed, the chemical reactions processes leading to SIA formation involve precursor gases such as sulphuric acid $\left(\mathrm{H}_{2} \mathrm{SO}_{4}\right)$, nitric acid $\left(\mathrm{HNO}_{3}\right)$, hydrochloric acid $(\mathrm{HCl})$ and $\mathrm{NH}_{3}$. The $\mathrm{H}_{2} \mathrm{SO}_{4}$ and $\mathrm{HNO}_{3}$ are oxidation products of gaseous sulphur dioxide $\left(\mathrm{SO}_{2}\right)$ and nitrogen oxides $\left(\mathrm{NO}_{\mathrm{x}}\right)$, respectively, while $\mathrm{NH}_{3}$ is directly emitted from its sources. Secondary sulphate particles in the atmosphere may exist as sulphuric acid, ammonium sulphate $\left(\mathrm{NH}_{4}\right)_{2} \mathrm{SO}_{4}$ or ammonium bisulphate $\left(\mathrm{NH}_{4} \mathrm{HSO}_{4}\right)$ and the formation of each depends on the amount of $\mathrm{NH}_{3}$. If enough $\mathrm{NH}_{3}$ is present, the particulate sulphate will be found as $\left(\mathrm{NH}_{4}\right)_{2} \mathrm{SO}_{4}$. Ammonium nitrate $\left(\mathrm{NH}_{4} \mathrm{NO}_{3}\right)$ and ammonium chloride $\left(\mathrm{NH}_{4} \mathrm{Cl}\right)$ are formed via reversible phase equilibrium with precursor gases such as $\mathrm{NH}_{3}, \mathrm{HNO}_{3}$ and $\mathrm{HCl}$ and the thermodynamic equilibrium between gas and particle phase depends on the ambient temperature and relative humidity. Thus, the Formation of $\mathrm{NH}_{4} \mathrm{NO}_{3}$ and $\mathrm{NH}_{4} \mathrm{Cl}$ is favoured under conditions of high relative humidity and low temperature. Given that the affinity of $\mathrm{H}_{2} \mathrm{SO}_{4}$ for $\mathrm{NH}_{3}$ is larger than that of $\mathrm{HNO}_{3}$ and $\mathrm{HCl}$ the available $\mathrm{NH}_{3}$ is first taken up by sulphuric acid to form ammonium sulphate salts. Any excess $\mathrm{NH}_{3}$ available may then react with nitric and hydrochloric acid to form ammonium nitrate and chloride.

During the measurement campaign the chemistry of $\mathrm{PM}_{1}$ (on $24 \mathrm{~h}$ base) was only available at the UB site and due to technical problems the number of $\mathrm{PM}_{1}$ filters simultaneously sampled with $\mathrm{NH}_{3}$ was reduced down to 24. Mean $\mathrm{NH}_{4}^{+}$, $\mathrm{SO}_{4}^{2-}, \mathrm{NO}_{3}^{-}$, and $\mathrm{Cl}^{-}$concentrations in $\mathrm{PM}_{1}$ filters at $\mathrm{UB}$ site for the campaign period were $0.83 \mu \mathrm{g} \mathrm{m}^{-3}, 2.85 \mu \mathrm{g} \mathrm{m}^{-3}$, $0.10 \mu \mathrm{g} \mathrm{m}^{-3}$ and $0.22 \mu \mathrm{g} \mathrm{m}^{-3}$, respectively. As shown in Table $2, \mathrm{NH}_{4}^{+}$aerosol was clearly associated with $\mathrm{SO}_{4}^{2-}$ with a coefficient of determination of 0.8 . However, $\mathrm{NH}_{4}^{+}$was not correlated $\left(R^{2}<0.1\right)$ with $\mathrm{NO}_{3}^{-}$and $\mathrm{Cl}^{-}$(not shown in Table 2). Therefore, and taking into account the relatively low concentrations of $\mathrm{NO}_{3}^{-}$and $\mathrm{Cl}^{-}$with respect to $\mathrm{SO}_{4}^{2-}$, the presence of ammonium sulfate salts was evidenced. The average equivalent ratio of $\mathrm{NH}_{4}^{+}$to $\mathrm{SO}_{4}^{2-}$ was 0.89 with daily ratios varying from 0.6 to 1.4 . A ratio of 1 indicates the presence of $\left(\mathrm{NH}_{4}\right)_{2} \mathrm{SO}_{4}$, whereas a value of 0.5 suggests the formation of $\mathrm{NH}_{4} \mathrm{HSO}_{4}$. The average ratio $\mathrm{NH}_{4}^{+}$ to $\left(\mathrm{SO}_{4}^{2-}+\mathrm{NO}_{3}^{-}+\mathrm{Cl}^{-}\right)$was 0.75 , with daily ratios varying from 0.5 to 1.4 and the variation of these ratios may indicate differing degrees of aerosol neutralization. On average, the concentrations of $\mathrm{NH}_{3}$ measured at UB were enough for neutralization. This analysis was not possible for $\mathrm{CC}$ site given that at $\mathrm{CC}$ the concentrations of ammonium salts were not determined. Finally, during the measurement campaign $100 \%$ and $74 \%$ of ammonium and sulfates in $\mathrm{PM}_{10}$, respectively, were accumulated in the $\mathrm{PM}_{1}$ fraction. By contrast, during the study period, only $8 \%$ of $\mathrm{NO}_{3}^{-}$in $\mathrm{PM}_{10}$ was found in $\mathrm{PM}_{1}$. Therefore, secondary nitrates were characterized by a coarser size distribution and likely neutralized by calcium and/or sodium (Pérez et al., 2008; Harrison and Pio, 1983).

Finally, weekdays vs. weekend differences in the concentrations of reported species were studied by means of the non-parametric Kruskal-Wallis test (Kruskal and Wallis, 1952) by using two groups obtained by averaging the available data over the Monday-Friday and Saturday-Sunday periods. The null hypothesis of the Kruskal-Wallis test is that the populations, from which the samples originate, have the same median while the alternative is that the medians are different. In this work a statistically significant result will refer to a significance level of $5 \%$ (p-value lower than 0.05). At UB site statistically significant weekdays-weekend differences were observed for traffic related pollutants such as $\mathrm{NO}_{2}, \mathrm{NO}, \mathrm{BC}$ and $\mathrm{PM}_{\mathrm{x}}(p<0.008)$. A slight decrease on weekend was also observed for the concentrations of $\mathrm{NH}_{3}$ ( $p=0.04)$, while for the remaining parameters no significant difference were observed. Conversely, at CC site no significant differences were observed between weekdays and weekend for $\mathrm{NH}_{3}$ and $\mathrm{BC}$ concentrations. The lack of a weekly cycle at $\mathrm{CC}$ was related to both the short measurement period available at $\mathrm{CC}$ and the peculiar characteristic of the city centre of Barcelona where anthropogenic activities were habitually active also on weekends.

\subsection{Daily cycles}

Figure 5 shows the mean daily cycles of $\mathrm{NH}_{3}, \mathrm{BC}$, wind speed and direction measured at $\mathrm{CC}$ and UB measurement sites and averaged over the entire measurement periods available at the two stations. Thus, Fig. 5a-c shows the daily cycles at $\mathrm{CC}$ averaged over the 13 May-28 June period, while Fig. $5 \mathrm{~d}-\mathrm{f}$ shows the mean daily cycles at UB averaged over the 6 May-7 September period. Figure 6 shows the daily cycles of gases $\left(\mathrm{SO}_{2}, \mathrm{NO}_{2}, \mathrm{O}_{3}\right), \mathrm{PM}_{1}$ and $\mathrm{PM}_{2.5-10}$ concentrations, and meteorological parameters (temperature, relative humidity and solar radiation) measured at UB over the period 6 May-7 September. Meteorological data in Fig. 6 will be used as reference for both sites. In Fig. 5a the daily cycles of $\mathrm{NH}_{3}$ concentrations measured at UB (black lines) during both the UB and CC measurement periods were presented with a different scale (right-hand y-axis in Fig. 5a) for better comparing the dynamic of $\mathrm{NH}_{3}$ at both sites.

We will refer to the Figs. 5 and 6 in order to not only separately describe the characteristics of $\mathrm{NH}_{3}$ at $\mathrm{UB}$ and $\mathrm{CC}$ but also to study the differences in the daily evolution of $\mathrm{NH}_{3}$ between the two measurement stations. 

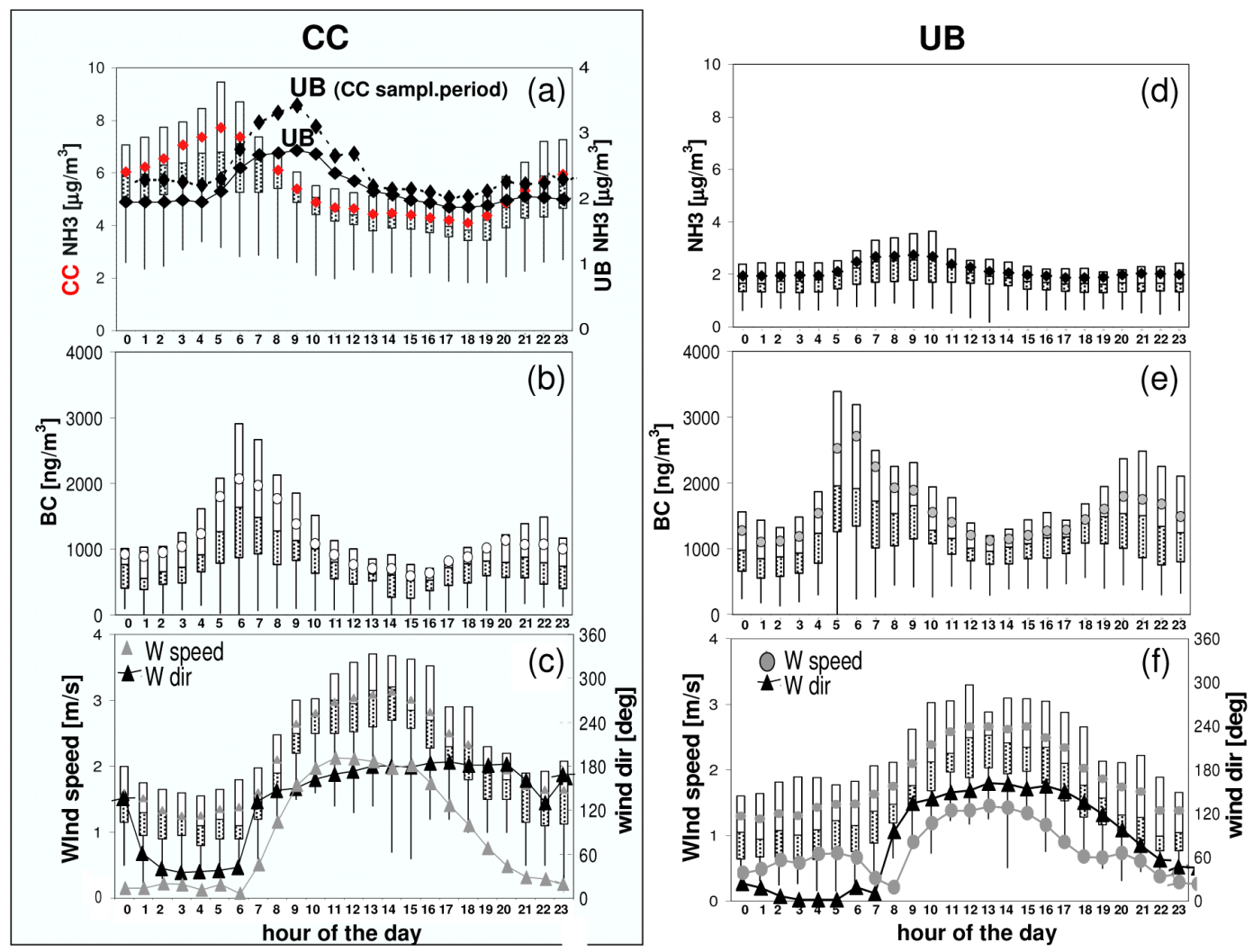

Fig. 5. Daily cycles of: (a) $\mathrm{NH}_{3}$ concentrations (red dots), (b) black carbon concentrations, and (c) vectorial (grey triangle in the box-andwhiskers plots) and scalar (grey solid line) wind speed and vectorial direction (black triangles) measured at CC over the period $13 \mathrm{May}-$ 28 June; and daily cycles of: (d) $\mathrm{NH}_{3}$ concentrations, (e) BC concentrations, (f) wind speed (scalar and vectorial) and direction (vectorial) measured at UB over the period 6 May-7 September. In Fig. 5a the concentrations of $\mathrm{NH}_{3}$ measured at UB over the periods 6 May7 September (black solid line) and 13 May-28 June (black dashed line) are also reported. Box-and whiskers plots represent the 25th and 50th percentiles (upper white and lower grey boxes), colored symbols represent the means, the black horizontal bands represent the median (50th percentiles) and lower error bars represent the minimum measured values.

In general, comparisons between different measurement sites should be done approximately over the same measurement period in order to avoid any bias due to possible changes in meteorological conditions or sources characteristics. However, as reported in Table 1, the differences between the concentrations of $\mathrm{NH}_{3}$ and ancillary data collected at UB and averaged over the whole UB period (6 May7 September) or over the CC period (13 May-28 June) were relatively small thus allowing the comparison between the two sites over different measurement periods. The feasibility of this approach is further demonstrated in the Supplement (Fig. S2) showing that the differences between the concentrations and daily cycles of data collected at UB and averaged over the two different measurement periods were relatively small. Differences were observed mainly for wind speed and direction. As reported in Fig. 5c during the period 13 May28 June the sea breeze at CC developed on average around 07:00 GMT with winds blowing from the sector 130-180 degrees. At UB (6 May-7 September) the sea breeze developed later around 08:00 GMT with the winds blowing approxi- mately from the same sector. As reported in the Supplement the temporal delay observed for the development of the sea breeze at the two sites was due to the different measurement periods. Thus, the sea breeze at UB also developed at around 07:00 GMT after averaging the UB wind data over the CC measurement period. Consequently, wind data were reported separately for both stations in Fig. 5 .

\subsection{1 $\mathrm{NH}_{3}$ levels at the old city (CC site)}

The levels of $\mathrm{NH}_{3}$ at $\mathrm{CC}$ site (Fig. 5a, red dots) showed a daily cycle driven mainly by the direction and velocity of the wind. The lowest wind velocities were measured between 00:00 and 06:00 GMT with scalar and vectorial means lower than $1.6 \mathrm{~m} \mathrm{~s}^{-1}$ and $0.2 \mathrm{~m} \mathrm{~s}^{-1}$, respectively. The vectorial means, which are weighted by the directions of the wind, reflected general stagnant conditions at night/early morning with winds blowing mainly from N-NE (black triangles in Fig. 5c) with low and rather constant velocities within a shallow nocturnal boundary layer. Under low dispersion 

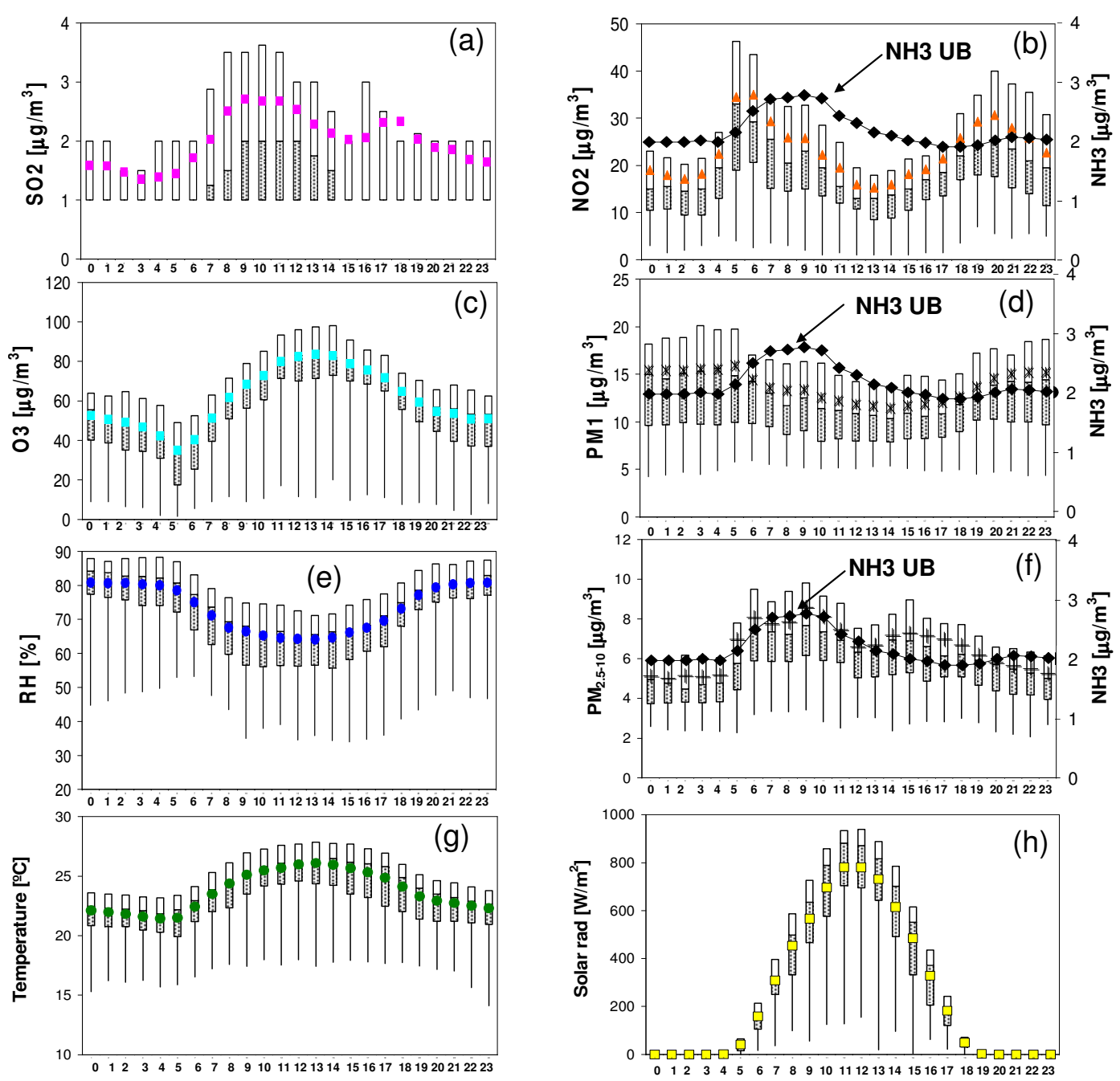

Fig. 6. Daily cycles of: (a) $\mathrm{SO}_{2}$ concentrations, (b) $\mathrm{NO}_{2}$ concentrations, (c) $\mathrm{O}_{3}$ concentrations, (d) $\mathrm{PM}_{1}$ concentrations, (e) relative humidity (RH), (f) $\mathrm{PM}_{2.5-10}$ concentrations, (g) temperature, and (h) solar radiation measured at UB over the period 6 May-7 September. In (b, d, f) the diurnal cycle of $\mathrm{NH}_{3}$ measured at UB over the 6 May-7 September period is also reported. Box-and whiskers plots represent the 25th and 50th percentiles (upper white and lower grey boxes), colored symbols represent the means, the black horizontal bands represent the median (50th percentiles) and lower error bars represent the minimum measured values.

conditions the ambient concentrations of $\mathrm{NH}_{3}$ and $\mathrm{BC}$ measured at $\mathrm{CC}$ accumulated with time reaching their highest mean values of more than $7.5 \mu \mathrm{g} \mathrm{m}^{-3}$ and $2000 \mathrm{ng} \mathrm{m}^{-3}$, respectively, around 05:00-06:00 GMT. The median concentrations of $\mathrm{BC}$ emitted by passing vehicles increased by around $200 \%$ between 01:00 GMT and 06:00 GMT (from 550 and $1640 \mathrm{ng} \mathrm{m}^{-3}$ ) while the medians $\mathrm{NH}_{3}$ concentrations increased by less than $20 \%$ (from $5.9 \mu \mathrm{g} \mathrm{m}^{-3}$ to $7.1 \mu \mathrm{g} \mathrm{m}^{-3}$ ). Despite the fact that BC is mainly emitted by diesel vehicles (60\% of the fleet in Barcelona), whereas $\mathrm{NH}_{3}$ is emitted by diesel and gasoline vehicles, the vehicle emissions were more effective in increasing the levels of $\mathrm{BC}$ above the values measured at night rather than those of $\mathrm{NH}_{3}$. The observed increase in $\mathrm{BC}$ concentrations was con- sistent with the increase of traffic density at these time periods (Fig. 3).

Starting from 07:00 GMT the increasing solar radiation (Fig. 6h) and temperature (Fig. 6g) activated the sea breeze characterized by winds blowing, with increasing velocities, from the S-SE direction (from the Sea) reaching relatively constant values of more than $3 \mathrm{~m} \mathrm{~s}^{-1}$ (scalar) and $2 \mathrm{~m} \mathrm{~s}^{-1}$ (vectorial) between 11:00 and 15:00 GMT. The cleansing effect of the sea breeze led to the observed gradual reduction in the concentrations of $\mathrm{NH}_{3}$ and $\mathrm{BC}$ observed in the morning. The $\mathrm{NH}_{3}$ and $\mathrm{BC}$ median concentrations reduced from $6.5 \mu \mathrm{g} \mathrm{m}^{-3}$ to $4.4 \mu \mathrm{g} \mathrm{m}^{-3}(\sim 30 \%)$ and from around $1500 \mathrm{ng} \mathrm{m}^{-3}$ to $700 \mathrm{ng} \mathrm{m}^{-3}(\sim 50 \%)$ from 07:00 to 12:00 GMT, respectively. The lower relative reduction of $\mathrm{NH}_{3}$ median concentrations compared with $\mathrm{BC}$ was likely 

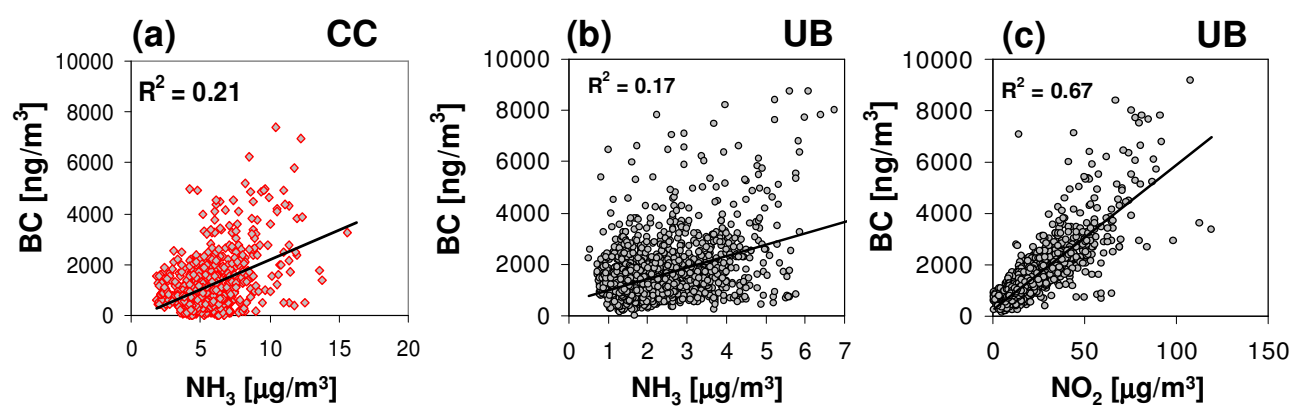

Fig. 7. Correlation between: (a) $\mathrm{NH}_{3}$ and $\mathrm{BC}$ concentrations at $\mathrm{CC}$, (b) $\mathrm{NH}_{3}$ and $\mathrm{BC}$ concentrations at $\mathrm{UB}$, and (c) $\mathrm{BC}$ and $\mathrm{NO} 2$ concentrations at UB.

due to the increasing evaporation of $\mathrm{NH}_{3}$ from other fugitive urban sources which contrasted the cleansing effect of the breeze and the possible depletion of $\mathrm{NH}_{3}$ due to the formation of ammonium salts.

The concentrations of $\mathrm{NH}_{3}$ reached their minimum mean value $\left(4.1 \mu \mathrm{g} \mathrm{m}^{-3}\right)$ at 18:00 GMT with fairly constant mean concentrations around $4-4.5 \mu \mathrm{g} \mathrm{m}^{-3}$ observed between 13:00 and 18:00 GMT. Starting from 19:00 GMT the concentrations of $\mathrm{NH}_{3}$ accumulated again with time as wind velocity decreased reflecting the tendency toward the stagnant atmospheric conditions observed at night. The lowest BC mean concentrations (between 590 and $20640 \mathrm{ng} \mathrm{m}^{-3}$ ) were instead observed around 15:00-16:00 GMT when the sea breeze was fully developed. Then, the concentrations of BC increased again starting from 16:00 GMT reflecting the decreasing trend of wind velocities and consequent accumulation of $\mathrm{BC}$ emissions from traffic which was still high at 16:00 GMT (Fig. 3).

On average during the measurement campaign at $\mathrm{CC}$ site low correlation was observed between the hourly concentrations of $\mathrm{NH}_{3}$ and $\mathrm{BC}$ (Fig. 7a; $R^{2}=0.21$ ). Low $R^{2}(0.26)$ was also observed by correlating the hourly concentrations of $\mathrm{NH}_{3}$ and $\mathrm{BC}$ between 03:00 and 06:00 GMT (around 170 points, not shown) when traffic intensity (Fig. 3) and vehicle emissions increased under stagnant conditions at night. The observed poor correlation was a consequence of the higher number of sources and sinks affecting the ambient concentrations of $\mathrm{NH}_{3}$ compared with $\mathrm{BC}$. Poor correlation between the hourly concentrations of $\mathrm{NH}_{3}$ and $\mathrm{BC}$ was observed also at UB (Fig. 7b) while BC correlated well $\left(R^{2}>0.9\right)$ with $\mathrm{NO}_{2}$, being both components emitted mostly by passing vehicles (Fig. 7c).

A further evidence of the fact that non-traffic sources dominated the levels of $\mathrm{NH}_{3}$ at $\mathrm{CC}$ is given from Fig. 5a, b. The $\mathrm{BC}$ concentrations showed the typical bimodal diurnal cycle driven by increasing (morning) or decreasing (night) emissions from traffic coupled with meteorological conditions favoring the accumulation (low wind and shallow planetary boundary layer (PBL) at night) or dispersion (sea breeze and higher PBLs during the day) of pollutants. The $\mathrm{NH}_{3}$ concen- trations also showed the same peak in the early morning due to the start of the sea breeze after the stagnant nocturnal conditions. However, at night the $\mathrm{NH}_{3}$ concentrations increased monotonically from 19:00 to 06:00 GMT without showing the second peak around 20:00 GMT. The constant nocturnal $\mathrm{NH}_{3}$ increase observed at $\mathrm{CC}$ was not detected at UB where the $\mathrm{NH}_{3}$ levels were rather constant at night with a slight but detectable increase around 20:00 GMT due to traffic emissions (Fig. 5d). The observed monotonic increase of $\mathrm{NH}_{3}$ concentrations at $\mathrm{CC}$, under relatively stable nocturnal conditions with fairly constant temperature and humidity, suggested the presence of active non-traffic sources of $\mathrm{NH}_{3}$ at $\mathrm{CC}$ at night likely related with the night life in the historical city centre of Barcelona in summer. Relatively constant $\mathrm{NH}_{3}$ concentrations with time were instead observed when the sea breeze was fully developed blowing with high and relatively constant velocities (Fig. 5c). Mean $\mathrm{NH}_{3}$ concentrations of $4.5 \mathrm{\mu g} \mathrm{m}^{-3}$ with relatively low standard deviation of $1.0 \mu \mathrm{g} \mathrm{m}^{-3}$ were measured based on the 120 hourly data available between 12:00 and 14:00 GMT. The observed constant $\mathrm{NH}_{3}$ concentrations at these times are better represented in Fig. 8 showing the relationship between the frequency distribution of scalar wind velocities and the concentrations of $\mathrm{NH}_{3}$ (Fig. 8a) and BC (Fig. 8b). Given the low occurrence for wind velocities higher than $4.5 \mathrm{~m} \mathrm{~s}^{-1}$ the frequency distribution of hourly wind velocities in Fig. 8 was calculated for values between $0 \mathrm{~m} \mathrm{~s}^{-1}$ and $4.5 \mathrm{~m} \mathrm{~s}^{-1}$ ( $99.3 \%$ of occurrence). Figure 8 shows that the highest $\mathrm{BC}$ and $\mathrm{NH}_{3}$ concentrations were on average measured under low wind speeds and vice versa. Moreover, for wind speed higher than around $2.5 \mathrm{~m} \mathrm{~s}^{-1}$ the concentrations of $\mathrm{NH}_{3}$ were on average constant (horizontal dashed black line in Fig. 8), while BC decreased almost monotonically $\left(R^{2}>0.8\right)$. This demonstrates that besides meteorology different sources and processes were affecting the concentrations and evolution of $\mathrm{NH}_{3}$ at $\mathrm{CC}$ during the measurement campaign.

\subsection{2 $\mathrm{NH}_{3}$ levels at the urban background (UB site)}

As for the CC site the concentrations of aerosol components and gaseous pollutants measured at UB showed daily 


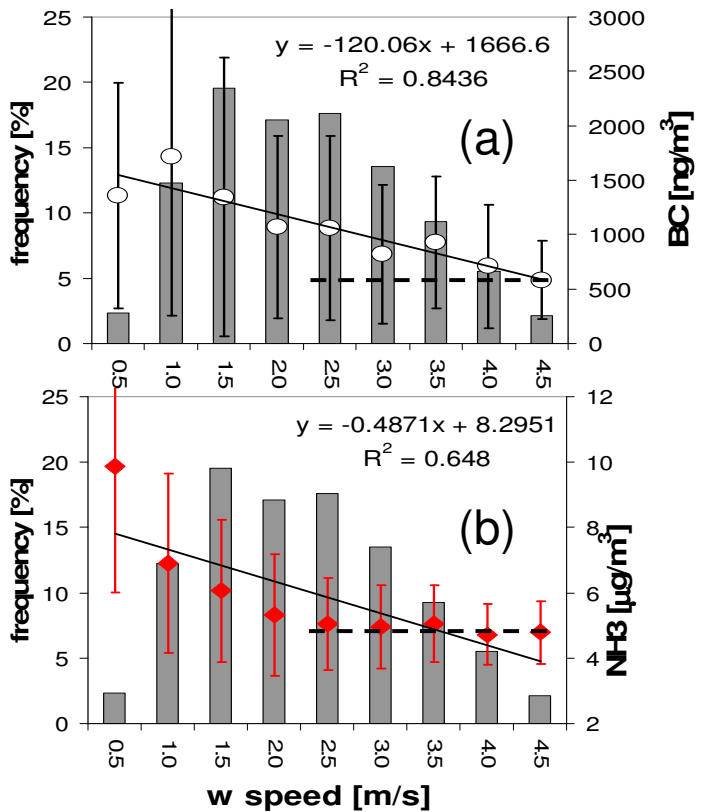

Fig. 8. Correlation between the frequency distribution (\%) of scalar wind velocity $\left(\mathrm{m} \mathrm{s}^{-1}\right)$ and (a) $\mathrm{BC}$ concentration and (b) $\mathrm{NH}_{3}$ concentrations at $\mathrm{CC}$.

cycles driven mainly by meteorology. The concentrations of $\mathrm{NO}_{2}$ (Fig. 6b) and $\mathrm{BC}$ (Fig. 5e) which as already noted were highly correlated at UB (Fig. 7c), increased in the early morning up to around 08:00 GMT with a peak around 05:0006:00 GMT mirroring the rush hours in the Diagonal Avenue. Then, the levels of traffic related pollutants decreased with time, as the velocity of the wind increased under the sea breeze circulation (Fig. 5f), reaching their minimum value around 13:00 GMT when the sea breeze was fully developed. Subsequently, traffic emissions accumulated again as wind velocity decreased and the concentrations of $\mathrm{BC}$ and $\mathrm{NH}_{3}$ showing a second peak at around 20:00 GMT. Thus the daily cycles of BC at UB and CC were fairly similar reflecting the similarities in the daily evolution of vehicles number and meteorology at both sites.

The concentrations of $\mathrm{NH}_{3}$ at UB increased in the morning from 06:00 GMT up to the development of the sea breeze which caused the observed reduction of $\mathrm{NH}_{3}$ levels at UB. As reported in Fig. 5 the concentrations of $\mathrm{NH}_{3}$ presented a relatively large peak in the morning compared with the concentrations of $\mathrm{NH}_{3}$ at $\mathrm{CC}$ (Fig. 5a) with relatively constant values from 07:00 to 10:00 GMT. The $\mathrm{NH}_{3}$ increase in the early morning at UB was likely due to the concomitance of different factors: traffic emissions, volatilization of secondary particles formed during the night under stagnant and cooler atmospheric conditions with the beginning of the solar activity around 06:00 GMT (Fig. 6h), transport of background $\mathrm{NH}_{3}$ from the old city and the Diagonal Avenue when sea breeze developed, or natural release of $\mathrm{NH}_{3}$ from vegetation and soil may have account for the observed morning increase in $\mathrm{NH}_{3}$ concentrations at UB. All these factors increased the levels of $\mathrm{NH}_{3}$ from around $2.1 \mu \mathrm{g} \mathrm{m}^{-3}$ (or $2.4 \mu \mathrm{g} \mathrm{m}^{-3}$ over the CC site sampling period) at 05:00 GMT up to $2.7 \mu \mathrm{g} \mathrm{m}^{-3}$ (or $3.5 \mu \mathrm{g} \mathrm{m}^{-3}$ ) at 09:00 GMT. Thus, an increase with respect to the values measured at night was clearly detectable at UB but it may have been masked at $\mathrm{CC}$ where the concentrations of $\mathrm{NH}_{3}$ were continuously increasing at night-early morning for the aforementioned reasons. Moreover, at CC a sudden entrance of clean air was guaranteed with the beginning of the sea breeze at 07:00 GMT given the proximity of the CC station to the sea causing the fast reduction of pollutants concentrations observed at CC.

Traffic emissions from the close Diagonal Avenue were in part responsible for the observed increase in $\mathrm{NH}_{3}$ levels in the morning and in the evening at UB. We will show in the next paragraph that the concentrations of $\mathrm{NH}_{3}$ at $\mathrm{UB}$ showed a clear bimodal diurnal cycle as $\mathrm{BC}\left(\right.$ or $\left.\mathrm{NO}_{2}\right)$ under specific atmospheric conditions favoring the accumulation of pollutants but that these conditions were not dominating during the summer measurement campaign. Figure $6 \mathrm{~d}$ shows that the daily cycles of $\mathrm{NH}_{3}$ and $\mathrm{PM}_{1}$ were anticorrelated in the early morning with $\mathrm{PM}_{1}$ concentrations decreasing from 06:00 GMT (before the development of the sea breeze) despite the increase in the concentrations of traffic tracers $\left(\mathrm{BC}, \mathrm{NO}, \mathrm{NO}_{2}\right)$ likely due to particle volatilization. Thus, volatilization of ammonium particles was also responsible, at least in part, for the observed $\mathrm{NH}_{3}$ morning increase.

Moreover, the transport of elevated background $\mathrm{NH}_{3}$ concentrations from the historical city centre and of $\mathrm{NH}_{3}$ emitted from the vehicle crossing the Diagonal Avenue downwind the measurement station, may occur at the beginning of the sea breeze when wind direction changed from 0 degrees at 07:00 GMT to around 120 degrees at 09:00-10:00 GMT. A prolonged morning peak at UB similar to that observed for $\mathrm{NH}^{3}$ was observed for the coarse $\mathrm{PM}$ mode $\left(\mathrm{PM}_{2.5-10}\right.$, Fig. 6f). The $\mathrm{PM}_{2.5-10}$ fraction in Barcelona is mainly composed by crustal material (wind blown and traffic resuspended dust) and marine aerosols (Amato et al., 2009, 2010). The increase in $\mathrm{PM}_{2.5-10}$ in the early morning (under stagnant conditions) was due to traffic-resuspended road dust from vehicles crossing the Diagonal Avenue. However, with the development of the sea breeze the transport of coarse aerosols from wind blown and traffic resuspended dust (also from construction works) from the historical city centre and marine aerosols from the sea may have contributed to the relatively constant values observed for the coarse aerosol mode between 06:00-10:00 GMT. The second peak at 15:00 GMT for $\mathrm{PM}_{2.5-10}$ concentrations was mainly due to coarse marine aerosols when sea breeze was fully developed (Amato et al., 2010). Thus, the similarities in the diurnal cycles of $\mathrm{NH}_{3}$ and $\mathrm{PM}_{2.5-10}$ in the morning suggest the transport of $\mathrm{NH}_{3}$ from the old city as concomitant effect affecting the concentrations of $\mathrm{NH}_{3}$ at $\mathrm{UB}$ station.

A common characteristic of $\mathrm{NH}_{3}$ diurnal cycles at $\mathrm{UB}$ and $\mathrm{CC}$ sites was the delay observed in $\mathrm{NH}_{3}$ concentrations in 


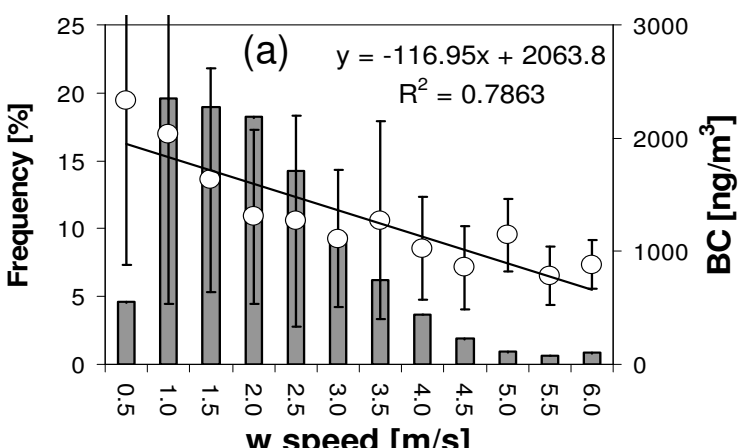

w speed $[\mathrm{m} / \mathrm{s}]$

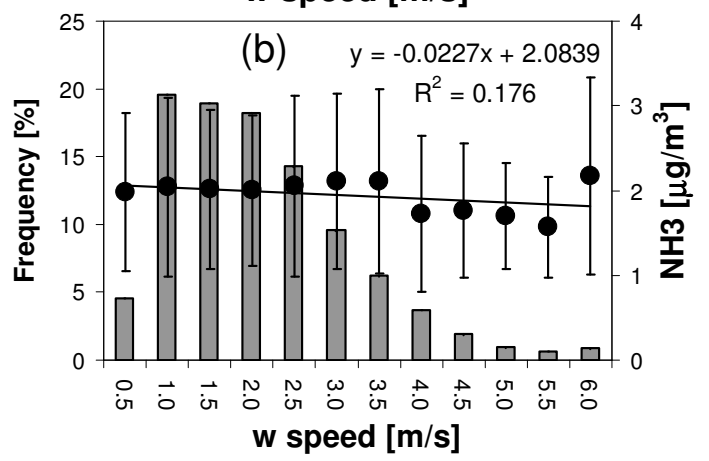

Fig. 9. Correlation between the frequency distribution (\%) of scalar wind velocity $\left(\mathrm{m} \mathrm{s}^{-1}\right)$ and (a) $\mathrm{BC}$ concentration and (b) $\mathrm{NH}_{3}$ concentrations at UB.

reaching their minimum values compared with $\mathrm{BC}$. Thus, at $\mathrm{UB}$ the minimum mean values for $\mathrm{NH}_{3}$ and $\mathrm{BC}$ were reached at 18:00 and 13:00 GMT, respectively. As for CC site, this delay was probably due to the continuous reduction in $\mathrm{NH}_{3}$ levels due to gas-to-particle partitioning in the afternoon. Conversely, at night from around 20:00 to 04:00 GMT the concentrations of $\mathrm{NH}_{3}$ at UB were rather constant with mean value of $2 \mu \mathrm{g} \mathrm{m}^{-3}$ and relatively low standard deviation of $0.7 \mu \mathrm{g} \mathrm{m}^{-3}$ on hourly base. This equilibrium condition for the $\mathrm{NH}_{3}$ concentrations at UB site was favored by the virtual absence at night of the continuously emitting non-traffic $\mathrm{NH}_{3}$ sources observed at $\mathrm{CC}$ site. The different behavior of $\mathrm{NH}_{3}$ and $\mathrm{BC}$ at UB is further shown in Fig. 9 where relationship between $\mathrm{BC}$ concentrations and wind speed was clearly observed $\left(R^{2}=0.78\right)$ while a low correlation was observed for $\mathrm{NH}_{3}$.

Thus, the differences observed between the concentrations and evolutions of $\mathrm{NH}_{3}$ at $\mathrm{UB}$ and $\mathrm{CC}$ were mainly due to the differences in the sources affecting both sites which determined the degree of equilibrium of ambient concentrations of $\mathrm{NH}_{3}$ under different atmospheric condition during the $24 \mathrm{~h}$.

\section{Specific cases}

As reported in the previous paragraphs different factors contributed to the measured concentrations and daily evolutions of $\mathrm{NH}_{3}$ in Barcelona in summer. We present and discuss in this section three cases observed during the campaign with levels and daily evolutions of $\mathrm{NH}_{3}$ dominated by specific sources or processes such as traffic emissions or gas-toparticle partitioning. Data from UB site were used with this aim given the larger dataset collected at this station compared with CC.

\subsection{SC1: traffic dominated scenario}

A closer analysis of each day of measurements performed at UB station revealed that a clear traffic-driven bimodal $\mathrm{NH}_{3}$ diurnal cycle, similar to that of $\mathrm{NO}_{2}$, was observed on 12 days (only weekdays) out of 90 days with simultaneous $\mathrm{NH}_{3}$ and $\mathrm{NO}_{2}$ measurements. Five out of these 12 days were consecutively observed between 9 and 13 May and the mean diurnal cycles of the measurements available at UB during this period (named SC1; ref. Fig. S1) are reported in Fig. 10 and compared with the mean diurnal cycles during the whole campaign.

As shown in Fig. 10 the beginning of the campaign was characterized by atmospheric conditions favoring the accumulation of pollutants. The mean concentrations of $\mathrm{NH}_{3}$, $\mathrm{PM}_{1}, \mathrm{PM}_{2.5-10}, \mathrm{NO}_{2}, \mathrm{BC}$ and $\mathrm{SO}_{2}$ during $\mathrm{SC} 1$ were higher compared with the whole campaign by around $32 \%, 65 \%$, $10 \%, 112 \%, 53 \%$ and $70 \%$, respectively. The lower increase was observed for the coarse PM mode $\left(\mathrm{PM}_{2.5-10}\right)$ indicating that these atmospheric conditions favored the accumulation mainly of fine particles. In fact, the mean concentration of $\mathrm{PM}_{1}$ under $\mathrm{SC} 1$, around $22.7 \mu \mathrm{g} \mathrm{m}^{-3}$, was higher than the mean value of $13.6 \mu \mathrm{g} \mathrm{m}^{-3}$ reported by Amato et al. (2009) for the 2003-2007 period. The opposite was observed for ozone which was around $37 \%$ lower than the mean. The SC1 period was characterize by low temperatures and wind speeds, less breeze and higher solar radiation and pressure. The analysis of the backtrajectories (not shown) indicated the lack of strong synoptic winds during these days with air masses coming mainly from the Mediterranean Sea thus explaining the reduction in temperature despite the slightly higher solar radiation. A certain degree of local recirculation of air masses was also observed thus explaining the accumulation of pollutants. Under these atmospheric conditions the $\mathrm{NH}_{3}$ emitted by passing vehicles were easily accumulated with $\mathrm{NH}_{3}$ showing the typical bimodal diurnal cycle, in parallel with $\mathrm{NO}_{2}$ and $\mathrm{BC}$, clearly related with traffic emissions during rush hours in the morning and in the evening when the sea breeze was not active.

The specific case under study demonstrated that traffic was an important source of $\mathrm{NH}_{3}$ at UB. On the base of previous publications in the area under study we know that the most intense stagnant atmospheric conditions leading to accumulation of pollutants were usually observed in winter (Jorba et al., 2011; Pandolfi et al., 2011; Pey et al., 2010). Thus, the traffic-driven bimodal diurnal cycles of $\mathrm{NH}_{3}$ can be expected to be more frequent in winter than in summer in Barcelona. Similar findings were reported for example by Meng et al. (2011) and Gong et al. (2011). 


\section{SC1: 09-13 May (Weekdays)}
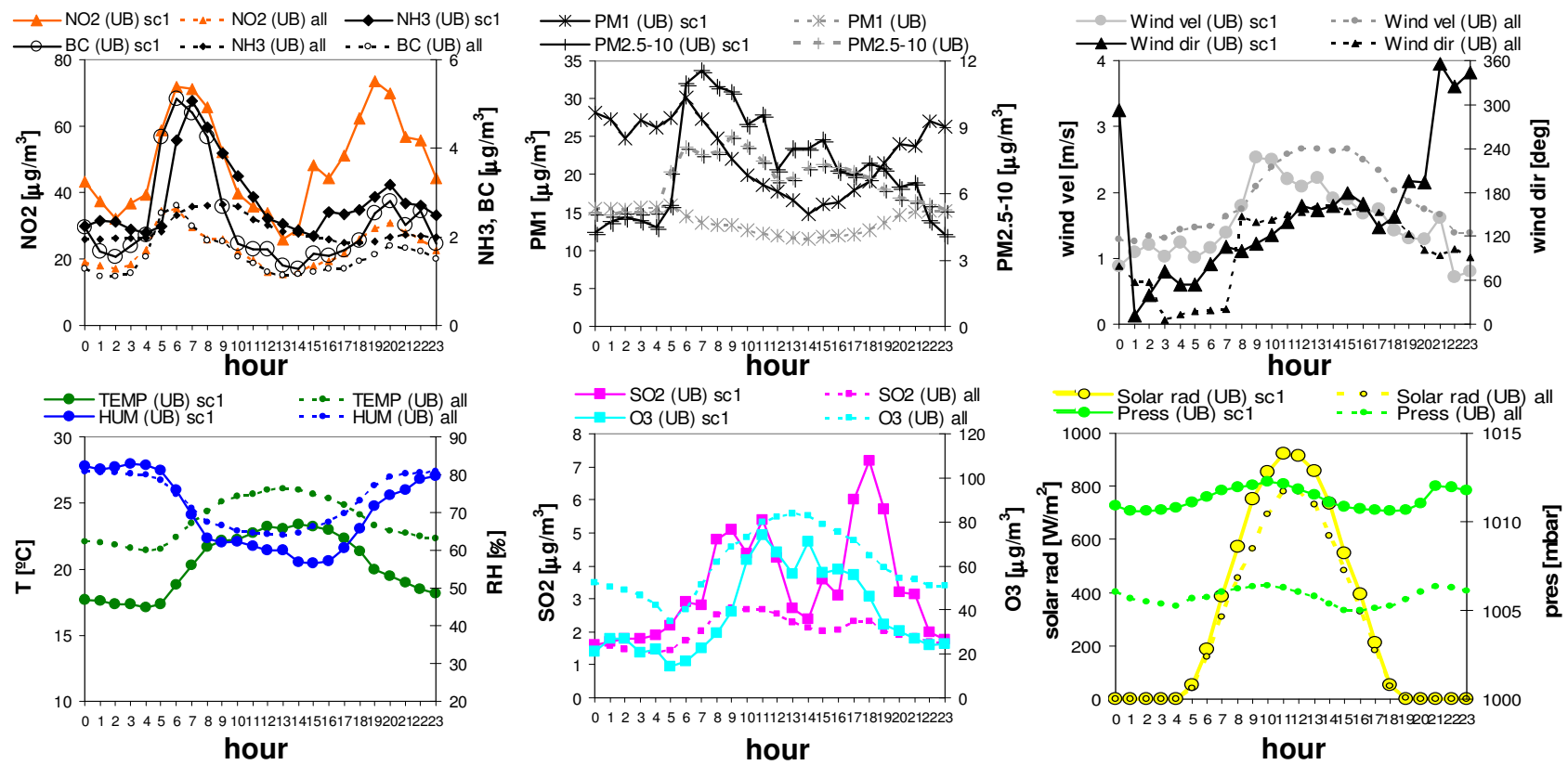

Fig. 10. Mean diurnal cycles of aerosol components and parameters measured at UB station during the period 9-13 May (Special Case 1).

\section{SC2: 01-05 Aug (Weekdays)}
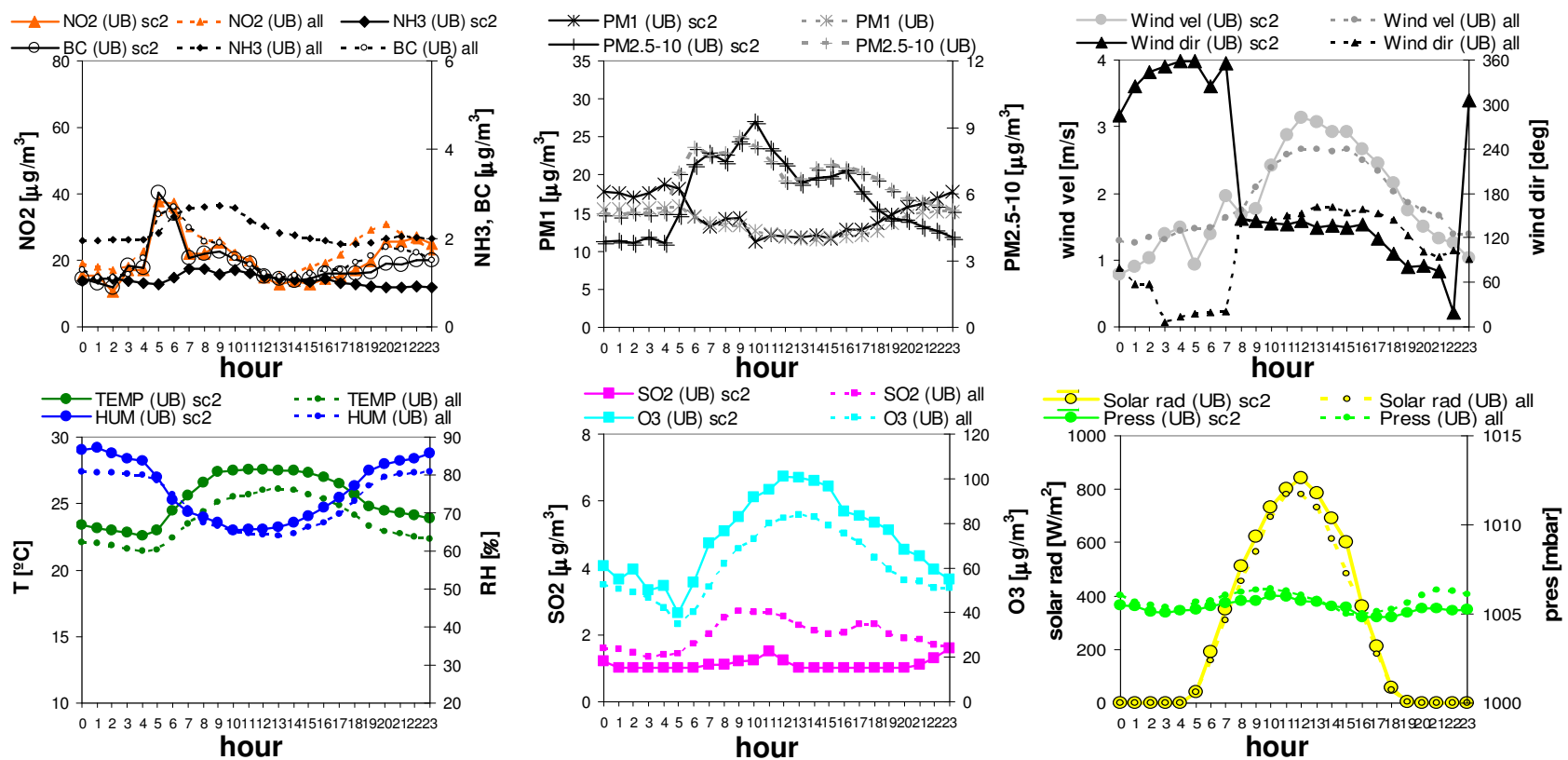

Fig. 11. Mean diurnal cycles of aerosol components and parameters measured at UB station during the period 1-5 August (Special Case 2).

\subsection{SC2: regional recirculation scenario}

Figure $\mathrm{S} 1$ shows that the measurement campaign at UB can be divided in two main periods: one from the beginning of the campaign up to around the first half of July with mean $\mathrm{NH}_{3}$ and $\mathrm{PM}_{1}$ levels of $2.7 \pm 1.0 \mu \mathrm{g} \mathrm{m}^{-3}$ and $15.8 \pm 6.7 \mu \mathrm{g} \mathrm{m}^{-3}$, respectively, and the other one from 15 July up to the end of the campaign with considerably lower mean concentrations of $\mathrm{NH}_{3}\left(1.6 \pm 0.7 \mu \mathrm{g} \mathrm{m}^{-3}\right)$ and $\mathrm{PM}_{1}\left(11.8 \pm 4.9 \mu \mathrm{g} \mathrm{m}^{-3}\right)$. The observed reduction in both $\mathrm{NH}_{3}$ and $\mathrm{PM}_{1}$ concentrations 


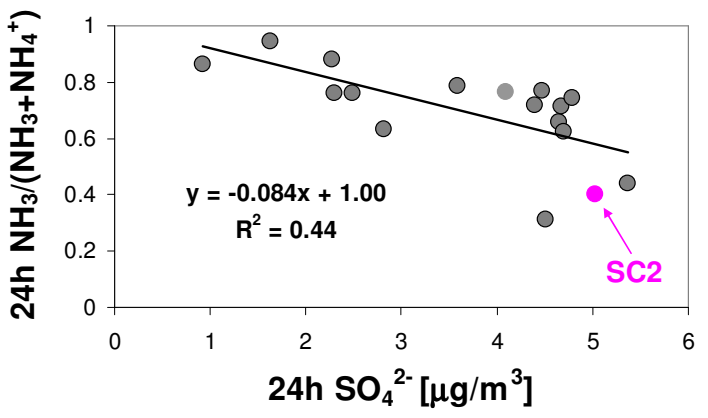

Fig. 12. Relationship between the gas fraction of ammonia $\left(\mathrm{NH}_{3} /\left(\mathrm{NH}_{3}+\mathrm{NH}^{4+}\right)\right)$ and sulfate $\left(\mathrm{SO}_{4}^{2-}\right)$ concentrations from $24 \mathrm{~h}$ filters collected over the period 10 May-5 August at UB.

was due to the typical summer recirculation/dispersion conditions enhanced during the second half of the campaign. The period 1-5 August (SC2; Monday-Friday), reported in Fig. 11, was characterized by these typical summer atmospheric conditions with sea breeze circulation and relatively high wind speed. Solar radiation and pressure were close to the mean values observed during the whole campaign while the temperatures registered under SC2 were considerably higher than the mean.

During SC2 the levels of $\mathrm{PM}_{1}$ and $\mathrm{NH}_{3}$ at UB were $14.8 \mu \mathrm{g} \mathrm{m}^{-3}$ and $1.0 \mu \mathrm{g} \mathrm{m}^{-3}$, respectively higher and lower than the corresponding means calculated over the second part of the campaign. Consequently, as reported in Fig. 11 the levels of $\mathrm{PM}_{1}$ under $\mathrm{SC} 2$ were similar to the levels measured during the whole campaign while the concentrations of $\mathrm{NH}_{3}$ were among the lowest on average measured. Figure 11 also show the lack of the clear bimodal diurnal profile of $\mathrm{NH}_{3}$ observed in Fig. 10 under more stagnant conditions. Our interpretation is that the enhanced formation of secondary sulfate during the days under study may cause the relative difference observed between the concentrations of $\mathrm{NH}_{3}$ and $\mathrm{PM}_{1}$ with respect to the mean values observed during the whole campaign. The influence of gas-particle partitioning on $\mathrm{NH}_{3}$ during the day with depletion of $\mathrm{NH}_{3}$ in favor of the formation of high concentrations of sulfates was recently presented by e.g. Ellis et al. (2011) in an agricultural area in Canada. Moreover, Reche et al. (2011) showed that in Barcelona in summer nucleation episodes involving $\mathrm{NH}_{4} \mathrm{HSO}_{4}$ particles formation are commonly observed at midday causing high levels of ultrafine particles.

Figure 12 shows the relationship between the $24 \mathrm{~h}$ averaged gas fraction $\mathrm{NH}_{3}$ (gas fraction $=\mathrm{NH}_{3} /\left(\mathrm{NH}_{3}+\right.$ $\left.\mathrm{NH}_{4}^{+}\right)$) and sulfate concentrations from off-line analysis of $24 \mathrm{~h}$ filters collected during the campaign. Twenty-two filters collected from 10 May to 5 August were available for this analysis. Details on experimental procedures used for the determination of $\mathrm{SO}_{4}^{2-}, \mathrm{NO}_{3}^{-}$and $\mathrm{NH}_{4}^{+}$from filters are given in Querol et al. (2001). Figure 12 shows that low ambient concentrations of $\mathrm{NH}_{3}$ in its gas fraction were avail- able when the concentrations of sulfate were high as expected from to the gas-to-particle conversion which in summer involved mainly the formation of secondary sulfates (mean value (22 filters) $=3.3 \mu \mathrm{g} \mathrm{m}^{-3}$ ) rather than nitrates (mean value $=0.3 \mu \mathrm{g} \mathrm{m}^{-3}$ ). Only one filter collected between 4 and 5 August was available during SC2 (highlighted in Fig. 12) and it was used as reference for the whole SC2 period. On the other end, the conditions during the selected 5 days were very stable and the mean diurnal cycles calculated on 4 and 5 August separately did not differ very much from the mean diurnal cycles calculated over the whole SC2 period (mainly showing low $\mathrm{NH}_{3}$, relatively high $\mathrm{PM}_{1}$ and temperatures).

Thus, during the specific case under study (SC2) the general atmospheric conditions, including higher mean temperatures, led to the formation of high concentrations of sulfate particles with consequent reduction in the concentrations of gas-phase $\mathrm{NH}_{3}$. Thus, the gas-to-particle conversion also played an important role during the campaign in the variation of $\mathrm{NH}_{3}$ concentrations.

\subsection{SC3: high $\mathrm{NH}_{3}$ episode}

The last specific case described in this section was the episode (one day, 13 July 2011) with the highest mean daily $\mathrm{NH}_{3}$ concentrations $\left(4.9 \mu \mathrm{g} \mathrm{m}^{-3}\right)$ registered during the whole campaign at UB. The mean diurnal cycle for 13 July was reported in Fig. 13.

The 13 July started with some rain at night around 03:0005:00 GMT causing the drastic reduction in the concentrations of the atmospheric components reported in Fig. 13 $\left(\mathrm{NH}_{3}, \mathrm{BC}, \mathrm{NO}_{2}, \mathrm{PM}_{1}\right.$ and $\left.\mathrm{PM}_{2.5-10}\right)$ scavenged by raindrops. High $\mathrm{NH}_{3}$ concentrations were instead observed before the rain event. This day was characterized by strong wind velocities and the virtual absence of sea breeze circulation, with winds blowing from the NW direction from 00:00 to 13:00 GMT. The high $\mathrm{NH}_{3}$ concentrations observed at night before the rain were likely due, in this specific case, to the transport of $\mathrm{NH}_{3}$ from forested areas located NW the city. High solar radiation and temperature were recorded at midday in concomitance with a reduction in $\mathrm{RH}$. The $\mathrm{NH}_{3}$ increase after the rain was likely due to the increased microbial processes in soil and vegetation that can release $\mathrm{NH}_{3}$ (e.g. Ellis et al., 2011) or from dew evaporation in the morning.

\section{Final considerations}

We have shown that the levels of $\mathrm{NH}_{3}$ in summer in Barcelona were regulated by different chemical and physical atmospheric processes. In the old city (CC measurement station) traffic did not dominate the measured concentrations of $\mathrm{NH}_{3}\left(5.6 \pm 2.1 \mu \mathrm{g} \mathrm{m}^{-3}\right.$ or $\left.7.5 \pm 2.8 \mathrm{ppbv}\right)$ which were higher compared with those simultaneously measured at the trafficinfluenced urban background station (UB) $\left(2.2 \pm 1.0 \mu \mathrm{g} \mathrm{m}^{-3}\right.$ 


\section{SC3: 13 July (Weekday)}
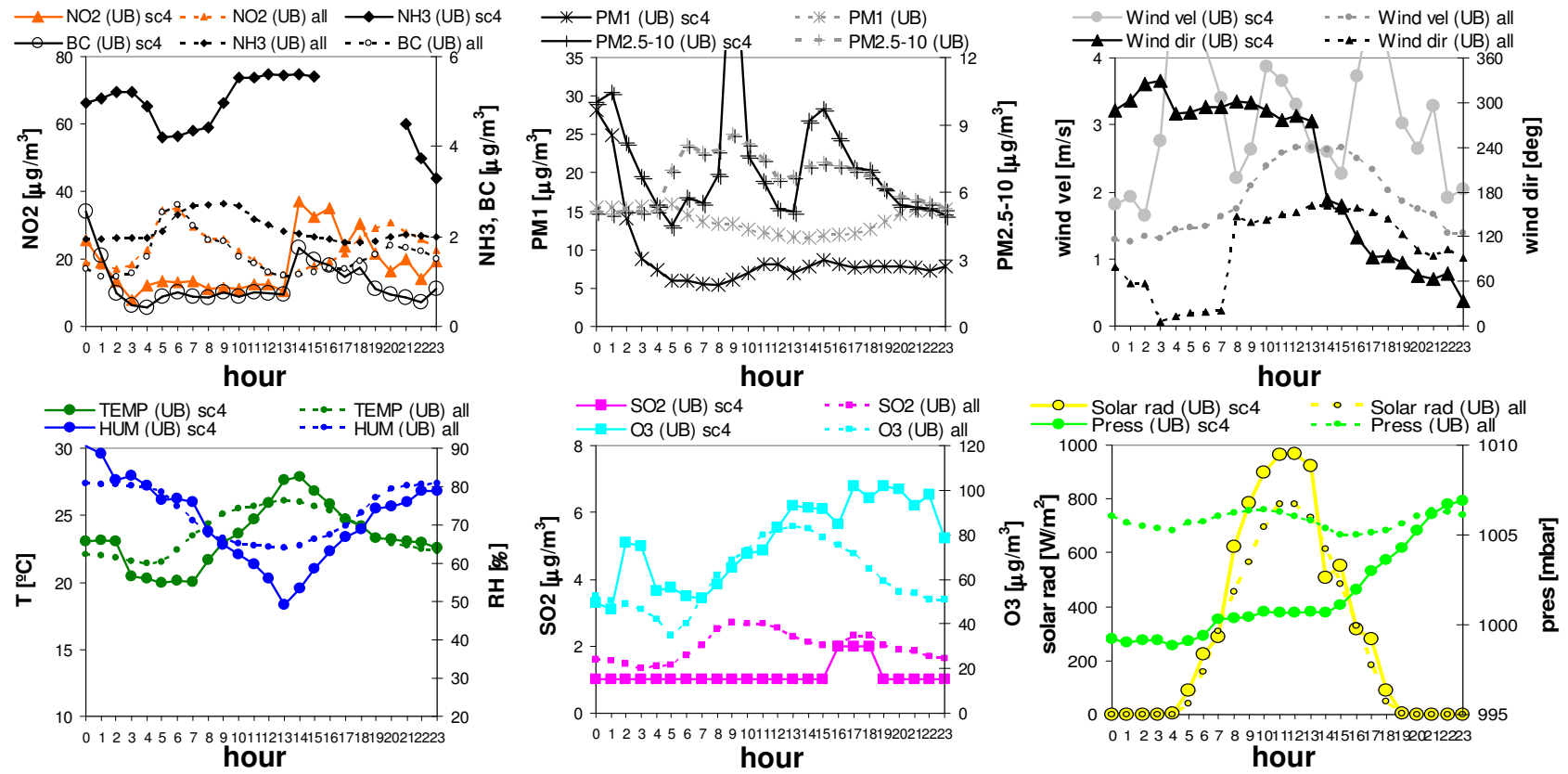

Fig. 13. Mean diurnal cycles of aerosol components and parameters measured at UB station during 13 July (Special Case 3).

or $2.9 \pm 1.3 \mathrm{ppbv}$ ) where higher $\mathrm{BC}$ concentrations and number of vehicles were observed compared with CC. Thus, other non-traffic fugitive $\mathrm{NH}_{3}$ sources such as waste containers, sewage systems, humans and open markets strongly contributed to the measured levels of $\mathrm{NH}_{3}$ in the densely populated old city of Barcelona.

In summer, under high atmospheric temperatures, these fugitive emissions had the potential to increase the concentrations of $\mathrm{NH}_{3}$ well above the levels measured at the trafficinfluenced urban background UB site. Moreover, the urban design of the old city of Barcelona with narrow streets also favored the accumulation of $\mathrm{NH}_{3}$ preventing the dispersion of air pollutants.

At UB the lower contribution from non-traffic $\mathrm{NH}_{3}$ sources compared with $\mathrm{CC}$ led to a more marked effect of traffic emissions which contributed to the $\mathrm{NH}_{3}$ increase observed in the morning and in the evening during the rush hours. Conversely, at night-early morning, when traffic intensity was low, the $\mathrm{NH}_{3}$ concentrations at UB were constant indicating that equilibrium between the $\mathrm{NH}_{3}$ sources and sinks was reached under relatively stagnant atmospheric conditions at night.

The typical bimodal-traffic-driven $\mathrm{NH}_{3}$ diurnal cycle at UB was especially marked at the beginning of the campaign when the lack of synoptic winds favored the accumulation of pollutants. This bimodal diurnal cycle was not observed at CC site where the $\mathrm{NH}_{3}$ concentrations showed a monotonic increasing tendency at night-early morning (from 19:00 to 05:00 GMT) before the development of the sea breeze as a consequence of the emissions from non-traffic $\mathrm{NH}_{3}$ sources in the old city which were active also during the night.

From the off-line analysis of the $24 \mathrm{~h}$ filters collected during this summer measurement campaign resulted that lower ambient concentrations of $\mathrm{NH}_{3}$ in its gas fraction were available when the concentrations of sulfate were high as expected from to the gas-to-particle conversion which in Barcelona in summer involved mainly the formation of secondary sulfates (mean value $=3.3 \mu \mathrm{g} \mathrm{m}^{-3}$ ) rather than nitrates (mean value $=0.3 \mu \mathrm{g} \mathrm{m}^{-3}$ ). Thus, the gas-to-particle conversion also played an important role during the campaign in the variation of $\mathrm{NH}_{3}$ concentrations.

The levels of $\mathrm{NH}_{3}$ measured in Barcelona, especially high in the old city, may contribute to the high mean annual concentrations of secondary sulfate and nitrate measured in Barcelona compared with other cities in Spain affected by high traffic intensity. In Madrid (around 3 millions inhabitants) for example considerably lower concentrations of $\mathrm{NH}_{3}$ have been observed (not shown) compared with Barcelona. These high $\mathrm{NH}_{3}$ concentrations in Barcelona may also explain the increase of around $4 \mu \mathrm{g} \mathrm{m}^{-3}$ in the mean annual concentrations of fine PM $\left(\mathrm{PM}_{2.5}\right)$ measured in Barcelona compared with Madrid. Finally, the concentrations of $\mathrm{NH}_{3}$ measured in Barcelona may also be the reason for the nucleation episodes involving $\mathrm{NH}_{4} \mathrm{HSO}_{4}$ formation which have been observed in Barcelona and which caused high levels of ultrafine particles (Reche et al., 2011). Consequently, we conclude that it is important to take specific measures in 
order to reduce the emissions of $\mathrm{NH}_{3}$ in the city of Barcelona and mainly in the old city.

\section{Supplementary material related to this article is available online at: http://www.atmos-chem-phys.net/12/ 7557/2012/acp-12-7557-2012-supplement.pdf.}

Acknowledgements. This work is supported by the MICINN (Spanish Ministry of Science and Innovation) and FEDER funds under the project CARIATI (CGL2008-06294/CLI), GRACCIE (CSD2007-00067), and by the European Union (6th framework CIRCE IP, 036961). The authors thank the Department of Environment of the Autonomous Government of Catalonia for providing the concentrations of gaseous pollutants and the Faculty of Physics from Barcelona University for providing meteorological data.

Edited by: E. Vignati

\section{References}

Air Quality Guidelines for Europe, 2nd Edn., World Health Organization Regional Office for Europe, European Series No. 91, WHO Regional Publications, ISBN 92-890-1358-3, Copenhagen, 2000.

Amato, F., Pandolfi, M., Escrig, A., Querol, X., Alastuey, A., Pey, J., Perez, N., and Hopke, P. K.: Quantifying road dust resuspension in urban environment by Multilinear Engine: A comparison with PMF2, Atmos. Environ., 43, 2770-2780, 2009.

Amato, F., Nava, S., Lucarelli, F., Querol, X., Alastuey, A., Baldasano, J. M., and Pandolfi, M.: A comprehensive assessment of PM emissions from paved roads: Real-world Emission Factors and intense street cleaning trials, Sci. Total Environ., 408, 43094318, 2010.

Aneja, V. P., Chauhan, J. P., and Walker, J. T.: Characterization of atmospheric ammonia emissions from swine waste storage and treatment lagoons, J. Geophys. Res.-Atmos., 105, 11535-11545, 2000.

Bari, A., Ferraro, V., Wilson, L. R., Luttinger, D., and Husain, L.: Measurements of gaseous $\mathrm{HONO}, \mathrm{HNO}_{3}, \mathrm{SO}_{2}, \mathrm{HCL}, \mathrm{NH}_{3}$, particulate sulfate and $\mathrm{PM}_{2.5}$ in New York City, Atmos. Environ., 37, 2825-2835, 2003.

Barthelmie, R. J. and Pryor, S. C.: Implications of ammonia emissions for fine aerosol formation and visibility impairment: a case study from the lower fraser valley, British Columbia, Atmos. Environ., 32, 345-352, 1998.

Brunekreef, B. and Holgate, S. T.: Air pollution and health, Lancet, 360, 1233-1242, 2002.

Burgard, D. A., Bishop, G. A., and Stedman, D. H.: Remote sensing of ammonia and sulfur dioxide from on-road light duty vehicles, Environ. Sci. Technol., 40, 7018-7022, 2006.

Cape, J. N., Tang, Y. S., van Dijka, N., Love, L., Sutton, M. A., and Pame, S. C. F.: Concentrations of ammonia and nitrogen dioxide at roadside verges, and their contribution to nitrogen deposition, Environ. Pollut., 132, 469-478, 2004.

Cape, J. N., van der Eerden, L. J., Sheppard, L. J., Leith, I. D., and Sutton, M. A.: Evidence for Changing the Critical Level for Ammonia, Environ. Pollut., 157, 1033-1037, 2009.
Carslaw, D. C. and Ropkins, K.: openair an R package for air quality data analysis, Environ. Modell. Softw., 27-28, 52-61, doi:10.1016/j.envsoft.2011.09.008, 2011.

Clarisse, L., Clerbaux, C., Dentener, F., Hurtmans, D., and Coheur, P.: Global ammonia distribution derived from infrared satellite observations, Nat. Geosci., 2, 479-483, doi:10.1038/ngeo551, 2009.

Durbin, T. D., Miller, J. W., Pisano, J. T., Sauer, C., Younglove, T., Rhee, S. H., Huai, T., and MacKay, G. I.: The effect of fuel sulfur on $\mathrm{NH}_{3}$ and other emissions from 2000-2001 model year vehicles, Atmos. Environ., 38, 2699-2708, 2004.

EC, 2001: EC, European Commission, Directive 2001/81/EC of the European Parliament and of the Council of 23 October 2001 on national emission ceilings for certain atmospheric pollutants, Official Journal, L309, 1-9, 2001.

EEA Technical Report: Air quality in Europe, No 12/2011, European Environment Agency, Luxenbourg, doi:10.2800/83213, 2011.

Edgerton, E. S., Saylor, R. D., Hartsell, B. E., Jansen, J. J., and Hansen, D. A.: Ammonia and ammonium measurements from the southeastern United States, Atmos. Environ., 41, 3339-3351, 2007.

Ellis, R. A., Murphy, J. G., Markovic, M. Z., VandenBoer, T. C., Makar, P. A., Brook, J., and Mihele, C.: The influence of gasparticle partitioning and surface-atmosphere exchange on ammonia during BAQS-Met, Atmos. Chem. Phys., 11, 133-145, doi:10.5194/acp-11-133-2011, 2011.

Erisman, J. W. and Sutton, M. A.: Reduced nitrogen in ecology and the environment: special issue of the ESF-FWF Conference in partnership with LFUI (October 2006), Environ. Pollut., 154, 357-358, doi:10.1016/j.envpol.2008.05.001, 2008.

Erisman, J. W., Otjes, R., Hensen, A., Jongejan, P., van den Bulk, P., Khlystov, A., Möls, H., and Slanina, S.: Instrument development and application in studies and monitoring of ambient ammonia, Atmos. Environ., 35, 1913-1922, 2001.

Erisman, J. W., Bleeker, A., Galloway, J., and Sutton, M. S.: Reduced nitrogen in ecology and the environment, Environ. Pollut., 150, 140-149, 2007.

Erisman, J. W., Galloway, J. A., Sutton, M. A., Klimont, Z., and Winiwater, W.: How a century of ammonia synthesis changed the world, Nat. Geosci., 1, 636-639, 2008.

Flechard, C. R., Nemitz, E., Smith, R. I., Fowler, D., Vermeulen, A. T., Bleeker, A., Erisman, J. W., Simpson, D., Zhang, L., Tang, Y. S., and Sutton, M. A.: Dry deposition of reactive nitrogen to European ecosystems: a comparison of inferential models across the NitroEurope network, Atmos. Chem. Phys., 11, 2703-2728, doi:10.5194/acp-11-2703-2011, 2011.

Fowler, D., Pitcairn, C. E. R., Sutton, M. A., Flechard, C., Loubet, B., Coyle, M., and Munro, R. C.: The mass budget of atmospheric ammonia in woodland within $1 \mathrm{~km}$ of livestock buildings, Environ. Pollut., 102, 343-348, 1998.

Fraser, M. P. and Cass, G. R.: Detection of excess ammonia emissions from in-use vehicles and the implications for fine particle control, Environ. Sci. Technol., 32, 1053-1057, 1998.

Gong, L., Lewicki, R., Griffin, R. J., Flynn, J. H., Lefer, B. L., and Tittel, F. K.: Atmospheric ammonia measurements in Houston, TX using an external-cavity quantum cascade laser-based sensor, Atmos. Chem. Phys., 11, 9721-9733, doi:10.5194/acp-11-97212011, 2011. 
Harrison, R. M. and Pio, C. A.: Size - differentiated composition of inorganic atmospheric aerosols of both marine and polluted continental origin, Atmos. Environ., 22, 1733-1783, 1983.

Heeb, N. V., Saxer, C. J., Forss, A.-M., and Brühlmann, S.: Correlation of hydrogen, ammonia and nitrogen monoxide (nitric oxide) emissions of gasoline-fueled Euro-3 passenger cars at transient driving, Atmos. Environ., 40, 3750-3763, 2006.

Heeb, N. V., Saxer, C. J., Forss, A.-M., and Brühlmann, S.: Trends of $\mathrm{NO}-, \mathrm{NO}_{2-}$, and $\mathrm{NH}_{3}$-emissions from gasoline-fueled Euro3- to Euro-4-passenger cars, Atmos. Environ., 42, 2543-2554, 2008.

Ianniello, A., Spataro, F., Esposito, G., Allegrini, I., Rantica, E., Ancora, M. P., Hu, M., and Zhu, T.: Occurrence of gas phase ammonia in the area of Beijing (China), Atmos. Chem. Phys., 10, 9487-9503, doi:10.5194/acp-10-9487-2010, 2010.

Ianniello, A., Spataro, F., Esposito, G., Allegrini, I., Hu, M., and Zhu, T.: Chemical characteristics of inorganic ammonium salts in $\mathrm{PM}_{2.5}$ in the atmosphere of Beijing (China), Atmos. Chem. Phys., 11, 10803-10822, doi:10.5194/acp-11-10803-2011, 2011.

Jorba, O., Pandolfi, M., Spada, M., Baldasano, J. M., Pey, J., Alastuey, A., Arnold, D., Sicard, M., Artiñano, B., Revuelta, M. A., and Querol, X.: The DAURE field campaign: meteorological overview, Atmos. Chem. Phys. Discuss., 11, 4953-5001, doi:10.5194/acpd-11-4953-2011, 2011.

Kean, A. J. and Harley, R. A.: On-road measurement of ammonia and other motor vehicle exhaust emissions, Environ. Sci. Technol., 34, 3535-3539, 2000.

Kean, A. J., Littlejohn, D., Ban-Weiss, G. A., Harley, R. A., Kirchstetter, T. W., and Lunden, M. M.: Trends in on-road vehicle emissions of ammonia, Atmos. Environ., 43, 1565-1570, 2009.

Kruskal, W. H. and Wallis, W. A.: Use of ranks in one-criterion variance analysis, J. Amer. Statist. Assoc., 47, 583-621, 1952.

Langridge, J. M., Lack, D. A., Brock, C. A., Bahreini, R., Middlebrook, A. M., Neuman, J. A., Nowak, J. B., Perring, A. E., Schwarz, J. P., Spackman, J. R., Holloway, J. S., Pollack, I. B., Ryerson, T. B., Roberts, J. M., Warneke, C., de Gouw, J., Trainer, M. K., and Murphy, D. M.: Evolution of aerosol properties impacting visibility and direct climate forcing in an ammonia-rich urban environment, J. Geophys. Res., 117, D00V11, doi:10.1029/2011JD017116, 2012.

Lin, Y. C., Cheng, M. T., Ting, W. Y., and Yeh, C. R.: Characteristics of gaseous $\mathrm{HNO}_{2}, \mathrm{HNO}_{3}, \mathrm{NH}_{3}$, and particulate ammonium nitrate in an urban city of Central Taiwan, Atmos. Environ., 40, 4725-4733, 2006.

Meng, Z. Y., Lin, W. L., Jiang, X. M., Yan, P., Wang, Y., Zhang, Y. M., Jia, X. F., and Yu, X. L.: Characteristics of atmospheric ammonia over Beijing, China, Atmos. Chem. Phys., 11, 61396151, doi:10.5194/acp-11-6139-2011, 2011.

Moeckli, M. A., Fierz, M., and Sigrist, M. W.: Emission factors for ethane and ammonia from a tunnel study with a photoacoustic trace gas detection system, Environ. Sci. Technol., 30, 2864 2867, 1996.

Müller, T., Henzing, J. S., de Leeuw, G., Wiedensohler, A., Alastuey, A., Angelov, H., Bizjak, M., Collaud Coen, M., Engström, J. E., Gruening, C., Hillamo, R., Hoffer, A., Imre, K., Ivanow, P., Jennings, G., Sun, J. Y., Kalivitis, N., Karlsson, H., Komppula, M., Laj, P., Li, S.-M., Lunder, C., Marinoni, A., Martins dos Santos, S., Moerman, M., Nowak, A., Ogren, J. A., Petzold, A., Pichon, J. M., Rodriquez, S., Sharma, S., Sheridan,
P. J., Teinilä, K., Tuch, T., Viana, M., Virkkula, A., Weingartner, E., Wilhelm, R., and Wang, Y. Q.: Characterization and intercomparison of aerosol absorption photometers: result of two intercomparison workshops, Atmos. Meas. Tech., 4, 245-268, doi:10.5194/amt-4-245-2011, 2011.

Nowak, J. B., Huey, L. G., Eisele, F. L., Tanner, D. J., Mauldin III, R. L., Cantrell, C., Kosciuch, E., and Davis, D. D.: Chemical ionization mass spectrometry technique for detection of dimethylsulfoxide and ammonia, J. Geophys. Res., 107, 4363, doi:10.1029/2001JD001058, 2002.

Nowak, J. B., Huey, L. G., Russell, A. G., Tian, D., Neuman, J. A., Orsini, D., Sjostedt, S. J., Sullivan, A. P., Tanner, D. J., Webber, R. J., Nenes, A., Edgerton, E., and Fehsenfeld, F. C.: Analysis of urban gas phase ammonia measurements from the 2002 Atlanta Aerosol Nucleation and Real-Time Characterization Experiment (ANARChE), J. Geophys. Res.-Atmos., 111, D17308, doi:10.1029/2006JD007113, 2006.

Nowak, J. B., Neuman, J. A., Bahreini, R., Brock, C. A., Middlebrook, A. M., Wollny, A. G., Holloway, J. S., Peischl, J., Ryerson, T. B., and Fehsenfeld, F. C.: Airborne observations of ammonia and ammonium nitrate formation over Houston, Texas, J. Geophys. Res., 115, D22304, doi:10.1029/2010JD014195, 2010.

Otjes, R. P. and Erisman, J. W.: Haalbaarheidstudie Miniaturisering Ammoniak Analyser (Feasibility Study on the Diminution of Ammonia Analyser), Report ECN-CX-99-015, ECN Energy Research Foundation The Netherlands, Petten, The Netherlands, 1999 (in Dutch).

Pandolfi, M., Cusack, M., Alastuey, A., and Querol, X.: Variability of aerosol optical properties in the Western Mediterranean Basin, Atmos. Chem. Phys., 11, 8189-8203, doi:10.5194/acp-11-81892011, 2011.

Pérez, N., Pey, J., Querol, X., Alastuey, A., Lopez, J. M., and Viana, M.: Partitioning of major and trace components in PM10-PM2.5PM1 at an urban site in Southern Europe, Atmos. Environ., 42, 1677-1691, 2008.

Perrino, C., Catrambone, M., Di Menno Di Bucchianico, A., and Allegrini, I.: Gaseous ammonia in the urban area of Rome,Italy and its relationship with traffic emissions, Atmos. Environ., 36, 5385-5394, 2002.

Pey, J., Rodríguez, S., Querol, X., Alastuey, A., Moreno, T., Putaud, J. P., and Van Dingenen, R.: Variations of urban aerosols in the western Mediterranean, Atmos. Environ., 42, 9052-9062, 2008.

Pey, J., Pérez, N., Querol, X., Alastuey, A., Cusack, M., and Reche, C.: Intense winter atmospheric pollution episodes affecting the Western Mediterranean, Sci. Total Environ., 408, 1951-1959, 2010.

Phillips, S. B., Arya, S. P., and Aneja, V. P.: Ammonia flux and dry deposition velocity from near-surface concentration gradient measurements over a grass surface in North Carolina, Atmos. Environ., 38, 3469-3480, 2004.

Querol, X., Alastuey, A., Rodríguez, S., Plana, F., Mantilla, E., and Ruiz, C. R.: Monitoring of $\mathrm{PM}_{10}$ and $\mathrm{PM}_{2.5}$ around primary particulate anthropogenic emission sources, Atmos. Environ., 35, 845-858, 2001.

Querol, X., Alastuey, A., Moreno, T., Viana, M.M., Castillo, S., Pey, J., Rodríguez, S., Artiñano, B., Salvador, P., Sánchez, M., Garcia Dos Santos, S., Herce Garraleta, M. D., Fernandez-Patier, R., Moreno-Grau, S., Negral, L., Minguillón, M. C., Monfort, E., Sanz, M. J., Palomo-Marín, R., Pinilla-Gil, E., Cuevas, E., de la 
Rosa, J., and Sánchez de la Campa, A.: Spatial and temporal variations in airborne particulate matter $\left(\mathrm{PM}_{10}\right.$ and $\left.\mathrm{PM}_{2.5}\right)$ across Spain 1999-2005, Atmos. Environ., 42, 3964-3979, 2008.

Reche, C., Querol, X., Alastuey, A., Viana, M., Pey, J., Moreno, T., Rodríguez, S., González, Y., Fernández-Camacho, R., de la Rosa, J., Dall'Osto, M., Prévôt, A. S. H., Hueglin, C., Harrison, R. M., and Quincey, P.: New considerations for PM, Black Carbon and particle number concentration for air quality monitoring across different European cities, Atmos. Chem. Phys., 11, 6207-6227, doi:10.5194/acp-11-6207-2011, 2011.

Reche, C., Viana, M., Pandolfi, M., Alastuey, A., Moreno, T., Amato, F., Ripoll, A., and Querol, X.: Urban $\mathrm{NH}_{3}$ levels and sources in a Mediterranean environment, Atmos. Environ., 57, 153-164, 2012.

Royal Decree 102/2011: available at: http://www.boe.es/boe/dias/ 2011/01/29/pdfs/BOE-A-2011-1645.pdf, 29 January 2011.

Saylor, R. D., Edgerton, E. S., Hartsell, B. E., Baumann, K., and Hansen, D. A.: Continuous gaseous and total ammonia measurements from the southeastern aerosol research and characterization (SEARCH) study, Atmos. Environ., 44, 4994-5004, 2010.

Sheppard, L. J., Leith, I. D., Mizunama, T., Cape, J. N., Crossley, A., Leeson, S., Sutton, M. A., van Dijk, N., and Fowler, D.: Dry deposition of ammonia gas drives species change faster than wet deposition of ammonium ions: evidence from a longterm field manipulation, Glob. Change. Biol., 17, 3589-3607, doi:10.1111/j.1365-2486.2011.02478.x, 2011.

Slanina, J., ten Brink, H. M., Otjes, R. P., Even, A., Jongejan, P., Khlystov, A., Waijers-Ijpelaan, A., and Hu, M.: The continuous analysis of nitrate and ammonium in aerosols by the steam jet aerosol collector (SJAC): extension and validation of the methodology, Atmos. Environ., 35, 2319-2330, 2001.
Sutton, M. A., Pitcairn, C. E. R., and Fowler, D.: The exchange of ammonia between the atmosphere and plant communities, Adv. Ecol. Res., 24, 301-393, 1993.

Sutton, M. A., Dragosits, U., Tang, Y. S., and Fowler, D.: Ammonia emissions from non-agricultural sources in the UK, Atmos. Environ., 34, 855-869, 2000.

Van der Hoek, K. W.: Estimating ammonia emission factors in Europe: summary of the work of the UNECE ammonia expert panel, Atmos. Environ., 32, 315-316, 1998.

von Bobrutzki, K., Braban, C. F., Famulari, D., Jones, S. K., Blackall, T., Smith, T. E. L., Blom, M., Coe, H., Gallagher, M., Ghalaieny, M., McGillen, M. R., Percival, C. J., Whitehead, J. D., Ellis, R., Murphy, J., Mohacsi, A., Pogany, A., Junninen, H., Rantanen, S., Sutton, M. A., and Nemitz, E.: Field inter-comparison of eleven atmospheric ammonia measurement techniques, Atmos. Meas. Tech., 3, 91-112, doi:10.5194/amt-3-91-2010, 2010.

Wyers, G. P., Otjes, R. P., and Slanina, J.: A continuous flow denuder for the measurement of ambient concentrations and surface-exchange of ammonia, Atmos. Environ., 27A, 20852090, 1993.

Zhao, B., Wang, P., Ma, J. Z., Zhu, S., Pozzer, A., and Li, W.: A high-resolution emission inventory of primary pollutants for the Huabei region, China, Atmos. Chem. Phys., 12, 481-501, doi:10.5194/acp-12-481-2012, 2012. 